\title{
Constant Pressure Flame Calorimetry With Fluorine II. The Heat of Formation of Oxygen Difluoride*
}

\author{
Reatha C. King and George T. Armstrong \\ Institute for Basic Standards, National Bureau of Standards, Washington, D.C. 20234
}

(December 27, 1967)

The heats of the following reactions were measured directly in an electrically calibrated flame calorimeter operated at one atm pressure and $303^{\circ} \mathrm{K}$.

$$
\begin{aligned}
\mathrm{OF}_{2}(\mathrm{~g})+2 \mathrm{H}_{2}(\mathrm{~g})+99 \mathrm{H}_{2} \mathrm{O}(\mathrm{l}) & \rightarrow 2\left[\mathrm{HF} \cdot 50 \mathrm{H}_{2} \mathrm{O}\right](\mathrm{l}) \\
\mathrm{F}_{2}(\mathrm{~g})+\mathrm{H}_{2}(\mathrm{~g})+100 \mathrm{H}_{2} \mathrm{O}(\mathrm{l}) & \rightarrow 2\left[\mathrm{HF} \cdot 50 \mathrm{H}_{2} \mathrm{O}\right](\mathrm{l}) \\
1 / 2 \mathrm{O}_{2}(\mathrm{~g})+\mathrm{H}_{2}(\mathrm{~g}) & \rightarrow \mathrm{H}_{2} \mathrm{O}(\mathrm{l})
\end{aligned}
$$

The reactants and products were analyzed for each of the reactions. From these heats we calculated the corresponding heats of formation, as follows:

$$
\begin{aligned}
\mathrm{OF}_{2} \text { (g) } \Delta H_{f 298.15}^{\circ} & =+24.52 \pm 1.59 \mathrm{~kJ} \mathrm{~mol}^{-1}\left(+5.86 \pm 0.38 \mathrm{kcal} \mathrm{mol}^{-1}\right) \\
\mathrm{HF} \cdot 50 \mathrm{H}_{2} \mathrm{O}(\mathrm{l}) \Delta H_{f 298.15}^{\circ} & =-320.83 \pm 0.38 \mathrm{~kJ} \mathrm{~mol}^{-1}\left(-76.68 \pm 0.09 \mathrm{kcal} \mathrm{mol}^{-1}\right) \\
\mathrm{H}_{2} \mathrm{O}(\mathrm{l}) \Delta H_{f 298.15}^{\circ} & =-285.85 \pm 0.33 \mathrm{~kJ} \mathrm{~mol}^{-1}\left(-68.32 \pm 0.08 \mathrm{kcal} \mathrm{mol}^{-1}\right)
\end{aligned}
$$

The uncertainties indicated are the estimates of the overall experimental errors. The value of the average $\mathrm{O}-\mathrm{F}$ bond energy in $\mathrm{OF}_{2}$ was calculated to be $191.29 \mathrm{~kJ} \mathrm{~mol}^{-1}\left(45.72 \mathrm{kcal} \mathrm{mol}^{-1}\right)$. Key Words: Bond energy $(\mathrm{O}-\mathrm{F})$, flame calorimetry, flow calorimetry, fluorine, heat of formation,
heat of reaction, hydrogen fluoride (aqueous), oxygen, oxygen difluoride, reaction
calorimetry, water.

\section{Introduction}

Thermochemical data for the fluorine oxidizers are very important for their present-day applications. This group of oxidizers includes elemental fluorine, and its compounds such as $\mathrm{OF}_{2}, \mathrm{ClF}_{3}, \mathrm{ClF}_{5}$, and $\mathrm{BrF}_{3}$. These substances are typically very reactive and combine with most other elements and compounds, yielding large heats of reaction and in many cases the highest valence state of the oxidized element. Two important uses of these oxidizers are for the production of fluorides, and as possible ingredients in rocket propellants and explosive systems. Because of their reactivity, they make possible chemical reactions which have not been investigated, e.g., reactions at extremely low temperatures.

Until a few years ago, very few thermochemical studies involving these materials had been conducted. This lack of work was caused mainly by the nonexistence of corrosion-resistant construction materials

*This research was sponsored by the Air Force Office of Scientific Research under Order No. OAR ISSA 65-8. For the first paper of this series see Reference [1]. and the unavailability of sufficiently pure samples the fluorides. In recent years several of the problents hindering earlier research have been solved, and precise calorimeiry has been demonstrated to be possible.

For measuring heats of reactions of the fluorine oxidizers, a new flame calorimetric apparatus has been set up in this laboratory. An earlier version of this apparatus has already been described $\left[1,2 \mid{ }^{1}\right.$ An investigation of the heat of formation of oxygen difluoride is the first study carried out with the new apparatus and is described in this presentation.

For many years there has been interest in the heat of formation of oxygen difluoride. In 1930, von Wartenberg and Klinkott [3], and Ruff and Menzel [4], reported two different thermochemical studies on this compound. In various reviews of thermochemical properties [5-8], the data from these studies have been reevaluated repeatedly in attempts to derive a selected "best" value for the heat of formation of this compound. For some time, the selected value for

\footnotetext{
${ }^{1}$ Figures in brackets indicate the literature references at the end of this paper.
} 
$\Delta H_{f 298.15}^{\circ}\left[\mathrm{OF}_{2}\right]$ was $+7.6 \mathrm{kcal} \mathrm{mol}^{-1}$ [5]. In 1965 Bisbee, et al. [9] reported on a more recent study from which they derived $\Delta H_{f 298.15}^{\circ}\left[\mathrm{OF}_{2}\right]=-4.06 \mathrm{kcal} \mathrm{mol}^{-1}$. In spite of the large amount of earlier work, there thus remained considerable uncertainty in the heat of formation of oxygen difluoride and, at the start of this work, it was not clear whether the compound was exothermic or endothermic. The results of the earlier experimental work are compared with those from the present study in another section of this paper. For comparison with the present experiments, it is important to mention here the reactions which were studied in the earlier investigations.

The measurements of von Wartenberg and Klinkott were carried out in a flow system in which they reacted $\mathrm{OF}_{2}(\mathrm{~g})$ with (1) $\mathrm{KOH}$ (excess $\mathrm{KOH}$ aq $40 \%$ ), (2) $|6 \mathrm{KI}+2 \mathrm{HF}|$ (in excess aq), and (3) $\mathrm{HBr}$ (excess $\mathrm{HBr}$, aq $45 \%$ ). They measured the heats of reaction and derived a value for the heat of formation of oxygen difluoride based on each reaction. Ruff and Menzel used a flame calorimeter to measure the heat of the overall reaction of combustion of $\mathrm{OF}_{2}$ with hydrogen and neutralization of the product $\mathrm{HF}$ in $\mathrm{NaOH}(\mathrm{aq})$. In the same apparatus they also measured the heats of the $\mathrm{F}_{2}-\mathrm{H}_{2}-\mathrm{NaOH}$ and the $\mathrm{O}_{2}-\mathrm{H}_{2}$ reactions. The latter measurements provide the auxiliary heat data needed for calculating $\Delta H_{f}^{\circ}\left[\mathrm{OF}_{2}\right]$. Bisbee, et al. reacted oxygen difluoride with hydrogen in a combustion bomb, which contained water for solution of the product HF. For calculating $\Delta \mathrm{H}_{f}^{\circ}\left[\mathrm{OF}_{2}\right]$ they obtained their auxiliary data for the $\mathrm{HF}(\mathrm{aq})$ from the literature. It is interesting to note that in the earlier work, three different calorimetric methods were used. With well-developed procedures, suitably selected reactions for study, and pure reaction materials, it seems possible that each of the above calorimetric methods could lead to a reliable value for $\Delta H_{f}^{\circ}\left[\mathrm{OF}_{2} \mid\right.$. However, it appears that these methods were not used to their best advantage in the earlier work.

There are few known reactions of oxygen difluoride which are suitable for a thermochemical study for deriving $\Delta H_{f}^{\circ}\left[\mathrm{OF}_{2} \mid\right.$. Because the magnitude of this heat-of-formation value is small, it is desirable to derive it from a reaction with a small heat effect. Such reactions with oxygen difluoride unfortunately tend to lead to multiple products, which are not readily recovered and separated for quantitative analysis. Under ordinary conditions fluorine and oxygen do not combine directly to form oxygen difluoride.

With the above points in mind, the $\mathrm{OF}_{2}-\mathrm{H}_{2}-\mathrm{H}_{2} \mathrm{O}$ reaction was selected for this study despite the large heat effects to be expected. This reaction leads to only a few products, goes readily to completion, is amenable to analysis of reactants and products, and requires auxiliary data that can be measured in the same apparatus. Oxygen difluoride was reacted with hydrogen in a flame, and then the product hydrogen fluoride was dissolved in water present in the reaction vessel. Using the same apparatus and similar procedures, heat measurements were made also for the $\mathrm{F}_{2}-\mathrm{H}_{2}-\mathrm{H}_{2} \mathrm{O}$ and $\mathrm{O}_{2}-\mathrm{H}_{2}$ reactions.

The reliability of the heat-of-formation value derived is increased by several factors inherent in this experi- mental plan. (1) The hydrogen fluoride is dissolved in water, yielding a well-defined thermodynamic state for the acid. (2) Dissolving the hydrogen fluoride inside the calorimeter lessens the possibility of loss of the acid by corrosion and retains it for later quantitative analyses. (3) Because the auxiliary data are measured in the same way as the principal reaction, several of the systematic errors cancel in the calculation of $\Delta H_{f}^{\circ}\left[\mathrm{OF}_{2}\right]$. This plan is similar to that used by Ruff and Menzel. Our work differs from theirs mainly in the solution of the hydrogen fluoride in water instead of aqueous sodium hydroxide, and in the design of the reaction vessel.

\section{Experimental Apparatus and Procedures}

\subsection{The Samples}

\section{a. Hydrogen}

A commercially available high purity grade of hydrogen was used. A mass spectrometric analysis was performed directly on the contents of the cylinder and the composition (mole percent) of the gas was: $\mathrm{H}_{2}, 99.9$; $\mathrm{H}_{2} \mathrm{O}, 0.04 \pm 0.02$; and $\mathrm{N}_{2}, 0.05 \pm 0.01$. The hydrogen was used directly from the cylinder.

\section{b. The Oxidizer Gases}

Commercially available samples of oxygen, fluorine, and oxygen difluoride were used. Each of the samples was transferred from the large cylinder to a spherical weighable container for the analyses and calorimetric experiments. The design of the sample containers has already been described $[1,2]$. They were constructed of Monel and equipped with either Monel or 316stainless-steel valves with Teflon packing. The weight of a typical bulb was approximately $150 \mathrm{~g}$. Extensive analyses were carried out for each of the gases and the procedures used are described in detail in the Appendix.

Oxygen. The oxygen was of high purity and is the grade used in this laboratory for bomb combustion experiments. The purity was reported by the supplier to be greater than 99.99 percent. It was analyzed for argon and nitrogen by mass spectrometry and gas chromatography, respectively. The composition of the sample is estimated to be oxygen, 99.987; nitrogen, 0.009 ; and argon, 0.004 weight percent.

Fluorine. The fluorine sample was of ordinary commercial quality and therefore not of the high purity desirable for a definitive thermochemical study of the hydrogen-fluorine reaction. While being sampled, the gas was passed over activated sodium fluoride for removal of hydrogen fluoride.

The total analysis of the fluorine sample was obtained using a combination of analytical methods. The total mole percent fluorine was determined by the mercury absorption technique and the relative amounts of the constituents of the residual gas were measured with mass spectrometry and gas chromatography. The chromatographic method was developed to provide a check on the results from the mass spectrometric method, which we have usually used 
for analysis of the residual gas. The results from the two methods were in good agreement (see appendix). Table 1 gives the complete analysis of the fluorine sample.

TABLE 1. Analysis of the fluorine sample

\begin{tabular}{|c|c|c|c|c|}
\hline \multirow[t]{2}{*}{ Constituent } & \multicolumn{2}{|c|}{$\begin{array}{l}\text { Mole percent } \\
\text { total impurities }\end{array}$} & \multirow{3}{*}{$\begin{array}{c}\text { Mole percent in } \\
\text { fluorine sample } \\
\text { (based on II) } \\
98.75\end{array}$} & \multirow[t]{2}{*}{$\begin{array}{l}\text { Weight } \\
\text { percent }\end{array}$} \\
\hline & $I^{b}$ & II & & \\
\hline$F_{2}$. & & & & 98.92 \\
\hline & 61.8 & 62.0 & 0.77 & 0.54 \\
\hline $\mathrm{O}_{2}$. & 28.6 & 31.3 & & .33 \\
\hline Ar.... & 0.2 & 0.2 & .0025 & .003 \\
\hline $\mathrm{CO}_{2} \ldots$ & 3.4 & 1.2 & .015 & .017 \\
\hline $\mathrm{CF}_{4} \ldots$. & 5.0 & 4.4 & .055 & .128 \\
\hline $\mathrm{SiF}_{4} \ldots$ & & 0.03 & .0004 & .001 \\
\hline $\mathrm{SO}_{2} \mathrm{~F}_{2} \ldots$ & 0.3 & .3 & .0037 & .010 \\
\hline $\mathrm{C}_{2} \mathrm{~F}_{6} \ldots$ & & .28 & .0035 & .013 \\
\hline $\mathrm{SF}_{6} \ldots$ & …...... & .08 & .0010 & .004 \\
\hline $\mathrm{C}_{3} \mathrm{~F}_{\mathrm{x}} \ldots \ldots \ldots \ldots \ldots$ & & .08 & .0010 & .005 \\
\hline 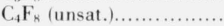 & & .07 & .0009 & .005 \\
\hline Remaining fluorocarbons & 0.6 & .06 & .0007 & . \\
\hline
\end{tabular}

a Mass spectrometric analysis of volatile impurities after removal of $\mathrm{F}_{2}$ by reaction with mercury.

bample pressure of I was factor of ten less than that of II. Analysis of I serves only for comparison of the analysis for major impurities.

Oxygen difluoride. The supplier's analysis of the oxygen difluoride sample showed it to contain: $\mathrm{OF}_{2}$, 99.25; $\mathrm{O}_{2}, 0.69$; and $\mathrm{CO}_{2}, 0.06$ weight percent, and 0.01 volume percent $\mathrm{CF}_{4}$. The gas was reported to contain no free fluorine. Kesting, et al. [10] compared the methods of gas chromatography, iodimetry and infrared spectroscopy for analysis of $\mathrm{OF}_{2}$ and their tests show that gas chromatography yields the most reproducible and accurate results.

Because of the importance of the analysis to the accuracy of the calorimetric data, the oxygen difluoride sample was reanalyzed in this laboratory by gas chromatography, following procedures similar to those described by Kesting. The results from two of the analyses are shown below.

\begin{tabular}{l|r|r|r}
\hline \hline \multirow{2}{*}{} & Analysis I & Analysis II & Av \\
\cline { 2 - 4 } & \multicolumn{2}{|c|}{ Mole \% } & wt. \% \\
\hline & 99.07 & 99.10 & 99.36 \\
$\mathrm{OF}_{2}$ & 0.76 & 0.73 & 0.45 \\
$\mathrm{O}_{2}$ & .06 & .07 & .11 \\
$\mathrm{CF}_{4}$ & .10 & .10 & .08 \\
$\mathrm{CO}_{2}$ & & & \\
\hline
\end{tabular}

For qualitative identification, an infrared spectrum of the sample was obtained and is shown in figure 11 (appendix).

\subsection{Reaction Vessel and Flow System Designs}

\section{a. The Reaction Vesse}

The general method is to react the oxidizer in a flowing atmosphere of excess hydrogen and then to form the aqueous acid solution of the products. The overall design is illustrated in figure 1. In the upper chamber (A) the oxidizer and hydrogen (excess) are mixed, ignited, and reacted in a flame. The effluent

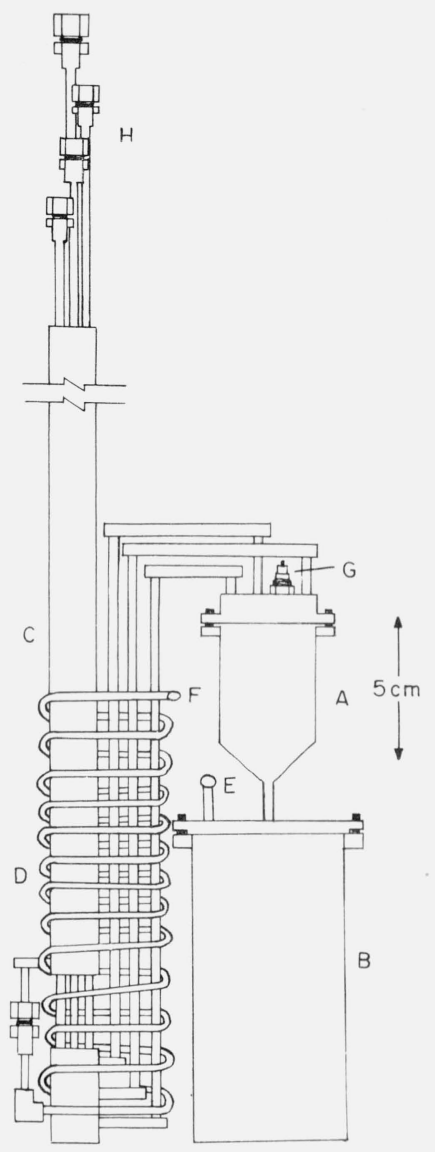

FiguRE 1. Burner for fluorine flame calorimetry

A, Combustion chamber; B, Primary solution vessel; C, Heat exchanger; D, Cooling coil; E, To secondary solution vessel; F, From secondary solution vessel; G, Igniter; H, Inlet and Outlet connectors

hydrogen removes the reaction products to the lower chamber (B), which is the primary solution vessel and contains $100 \mathrm{~cm}^{3}$ of water. A gas dispersion system forces the gas mixture as fine bubbles through the aqueous solution, to cause complete removal of the hydrogen fluoride from the flowing hydrogen, and simultaneously to mix the solution making it homogeneous in concentration and temperature.

The gases are brought to the burner from the exterior of the calorimeter system by Monel tubes passing through the heat exchanger (C). The exit gas enters from the coiled tube (D) into the lower end of the outer tube of the heat exchanger, and while leaving the calorimeter, circulates among the small tubes which contain the entering gases. The outlet $(\mathrm{E})$ on the primary solution vessel connects to a smaller vessel which is seen in the foreground in the complete burner assembly shown in figure 2 . For an experiment this secondary vessel contains $20 \mathrm{~cm}^{3}$ of water. As can be seen by reference to figures 1 and 2 , the effluent gases leave the secondary solution vessel at $\mathrm{F}$ and pass through a helix of Monel tubing before entering the heat exchanger. Except for the primary solution vessel, the reaction vessel is composed almost entirely of 


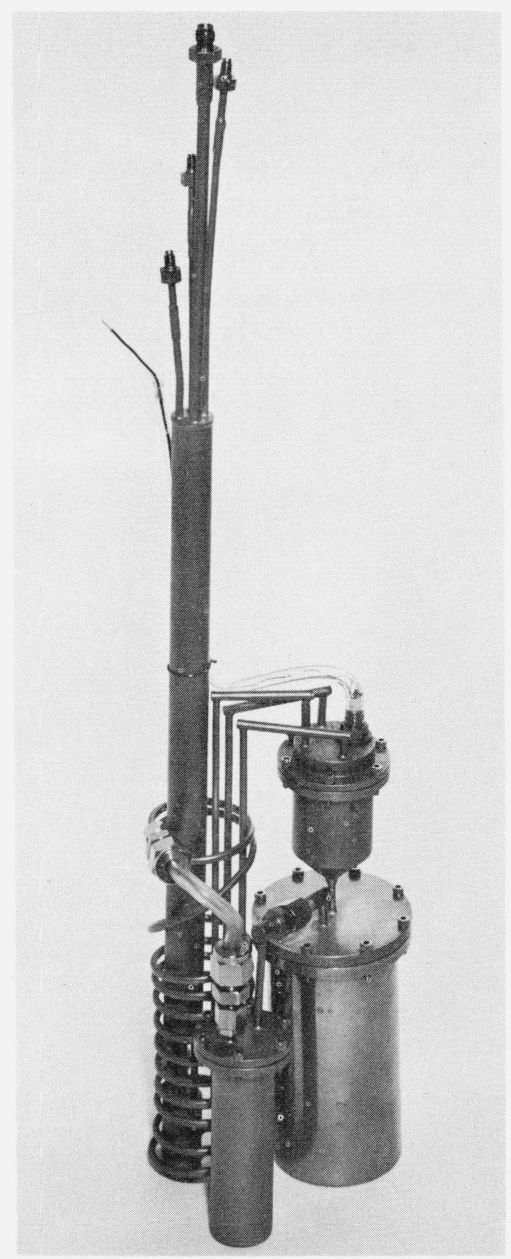

FigURE 2. Assembly of reaction vessel.

Monel and silver-sotdered at all of the permanent joints.

Details of the combustion chamber are shown in figure 3 . The inlet tubes for the reacting gases, the igniter, and the flame tip are attached to the lid of the combustion chamber so that they are readily accessible when the lid is removed. The oxidizer is introduced through inlet $\mathrm{C}$, and the major part of the hydrogen atmosphere enters through inlet B. Additional hydrogen is introduced through a third gas inlet (not shown). The joint between the cover and the combustion chamber is made by a Teflon gasket placed in a groove on the flange of the cup.

The reaction is initiated with an electric spark from a high voltage electrode which is a nickel rod, insulated by Teflon from a Monel sheath. A calcium fluoride disk is placed over the electrode $(\mathrm{E})$ to further shield it from the reaction heat and product hydrogen fluoride.

The platinum tube $(\mathrm{F})$ leading into the solution chamber is fitted with a polyethylene cap having a porous lower surface. The cap is held in place with a small Teflon adapter (G). The primary solution vessel is made of nickel-plated copper and has a Teflon liner.

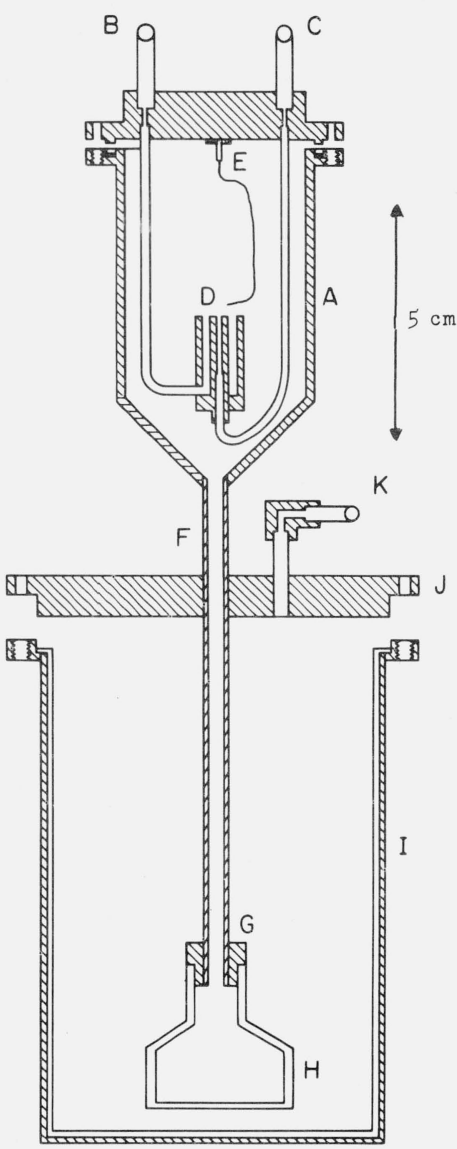

FIGURE 3. Combustion chamber and primary solution vessel.

A, Combustion chamber; B, Hydrogen inlet; C, Oxidizer inlet; D, Flame position; E, Spark electrode; F, Platinum tubing; G, Teflon adapter; H, Polyethylene gas disperser; $\mathrm{I}$, Primary solution chamber; J, Lid for solution vessel; K, To secondary solution vessel.

The flange on the liner makes the seal when the vessel is closed.

The water in the secondary solution vessel removes any hydrogen fluoride from the effluent gas that may be transferred from the primary solution. This provision assures also that upon leaving the burner the effluent gas flows through a solution for which the partial pressure of $\mathrm{HF}$ does not change during the experiment. In the primary solution vessel, the liquid contains no HF during the fore-period, but contains about two weight percent hydrogen fluoride in the final drift. The vapor pressure of hydrogen fluoride over the final solution is about $0.048 \mathrm{~mm} \mathrm{Hg}$ at $25^{\circ} \mathrm{C}$ [11]. Consequently, very little hydrogen fluoride is transferred to the secondary solution.

\section{b. The Flow System}

The layout of the gas flow system is similar to that used previously for flame calorimetric work in this laboratory $[1,2]$. The components of the flow system are schematically shown in figure 4 . Preceding the calorimeter are three flow lines which connect to inlet ports on the reaction vessel. These consist of the two flow lines for hydrogen, and one for the oxidizer. 


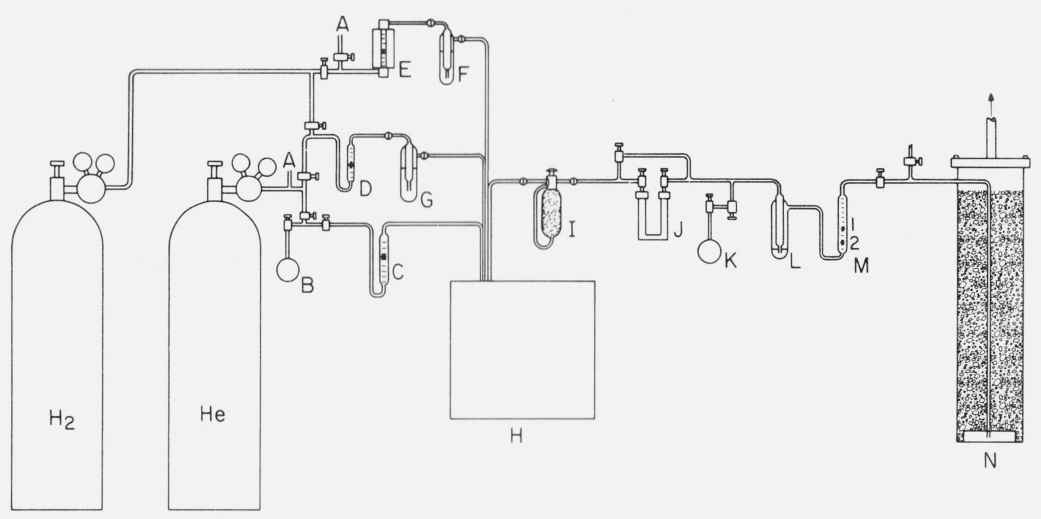

FigURE 4. Flow system.

A, Flow inlet (helium); B, Oxidizer sample container; C, Flowmeter (oxidizer); D. Flowmeter (hydrogen, II): E, Flowmeter (hydrogen, I); F, Saturator (I); G, Saturator (II); H, Calorimeter; I, Absorber (magnesium perchlorate); J, Absorber (sodium fluoride); K, Sampling bulb; L, Bubbler (Kel-F oil); M, Flowmeter (effluent gas); N, Fluorine absorption tower.

The oxidizer line begins with the spherical sample bulb at B. Not shown in the diagram is an absorber of magnesium perchlorate placed immediately after the helium cylinder. Predrying of the helium is desired for the helium that enters the fuel line, but as is explained below, dried helium is not necessary for the hydrogen lines. The flow rate of the oxidizer was regulated by manual adjustment of the valves.

Each hydrogen line includes a flowmeter and weighable "saturator." The saturator is Pyrex and with the water, weighs about 69 grams. The hydrogen entering the reaction vessel is saturated with water to compensate for the water removed by the effluent hydrogen.

The items after the calorimeter used in these experiments are the absorption bulb (I), the sampling bulb $(\mathrm{K})$, the bubbler $(\mathrm{L})$, and the flowmeter $(\mathrm{M})$. The absorption bulb contains magnesium perchlorate and is used to measure the amount of water removed from the reaction vessel by the effluent hydrogen. The final flowmeter is useful in monitoring the reaction. The remaining items serve the same purpose as described earlier [1].

\subsection{The Calorimeter and Its Operation}

The calorimeter is similar in design to the Dickinson Calorimeter [12], with modifications which were introduced by Prosen, et al. [13]. It is enclosed in a constanttemperature submarine-shield in the surrounding water bath. The calorimeter can is separated from the enclosure by a $1 / 2$-in air space. It is supported by three metal pegs and has a volume of 5.5 liters. The calorimeter lid has three holes for bringing out the platinum resistance thermometer, the leads to the electrical calibration heater, and the flow lines to the reaction vessel. The reaction vessel and most of the heat exchanger are immersed in the stirred water of the calorimeter. The water is stirred at a rate of $300 \mathrm{rpm}$. The reaction vessel is placed on a small brass platform, supported by three small cones. This positions the bottom of the reaction vessel about $1 / 4$ in above the bottom of the calorimeter can.
In the manner customary in this laboratory, temperature measurements were made with a calibrated platinum resistance thermometer, used in conjunction with a G-2 Mueller bridge and a high-sensitivity galvanometer. A displacement of $0.5 \mathrm{~mm}$ on the galvanometer scale represented $10 \mu \Omega$ on the bridge or one-tenth millidegree. At $0{ }^{\circ} \mathrm{C}$ the thermometer has a resistance of $25.4668 \Omega$.

The temperature of the jacket water was kept constant at $32{ }^{\circ} \mathrm{C}$ by an automatic regulating system consisting of a thermistor sensing element, linear dc microvolt amplifier, strip-chart recorder $(-5$ to $+5 \mu \mathrm{V})$, current-adjusting-type controller, and a $50-\mathrm{W}$ magnetic power amplifier [14. The jacket bath has two heaters, a $14-\Omega$ heater for raising the jacket temperature to $32{ }^{\circ} \mathrm{C}$, and a $131-\Omega$ heater for temperature control. A $500-\mathrm{mA}$ meter is connected between the magnetic amplifier and the control heater. The thermistors form two opposite arms of a Wheatstone bridge circuit of which the two remaining arms are formed by adjustable temperature-insensitive resistors. Each thermistor arm of the bridge consists of four bead thermistors of about $1000 \Omega$ each. The thermistors are encased in flattened thin-wall copper tubing and are immersed in the jacket water near the heaters and stirrer. A $1.5-\mathrm{V}$ mercury cell supplies a current of $0.040 \mathrm{~mA}$ to the bridge. The current is kept very small so that self heating of the thermistor elements remains below $0.001{ }^{\circ} \mathrm{C}$. The temperature was usually controlled to better than $\pm 0.0015^{\circ} \mathrm{C}$.

\section{a. Electrical Calibration System}

The calibration heater was made from B\&S gage No. 30 Advance wire covered with a double layer of glass insulation. The current leads were 22 -gage copper wire and the heater sheath was thin copper tubing flattened onto the resistance wire. The resistance of the heater was $23 \Omega$. The heater was formed in a 1-in o.d. coil which was suspended from the calorimeter lid. The ends of the sheath passed through a small copper plug which was fastened securely to a ring on the lid. 
The potential leads are attached so that there is a negligible disturbance in the current leads [15]. The first potential lead is soldered to the current lead just inside of the copper sheath at the physical boundary of the calorimeter. The three leads are then brought up to a copper plate and the second potential lead is attached at the point where the current lead contacts the copper plate. Then all four wires are coiled on the lower side of the plate and cemented firmly in place. By means of a bakelite rod, which passes through a tube in the submarine lid, the copper plate is secured firmly against the lower side of the submarine lid to achieve good thermal contact with the calorimeter shield.

The power for the electrical calibration was obtained from a precision regulated power supply. The unit has a power output of about $500 \mathrm{~W}$ maximum, with a current range from $0-5 \mathrm{~A}$ and a voltage range from 0-103 V. The supply was operated in the constant current mode.

With the parameters and switching arrangement in these experiments, operation in the current mode gave more constant current and voltage readings. The double-pole, double-throw switch which connects the calibration heater and a dummy heater of similar resistance alternately into the circuit posed a problem in the calibrations. While interchanging the heaters, a transient voltage appeared. In a separate investigation [16] the magnitude and decay time of this transient voltage were observed. Because the transients were over in about ten seconds, while the heating periods were usually about sixteen minutes long, we believe that this effect does not significantly affect the accuracy of the calibrations performed. Current and voltage readings were made on alternate minutes. The time interval for the electrical heating was measured with an electronic counter, with an internal quartz oscillator generating at $100 \mathrm{kHz}$, which gave the time readings to $10^{-5}$ second. The timer was actuated by the switching arrangement which initiated the heating to the calorimeter.

Other equipment used in measuring the electrical energy input consisted of a $0.01 \Omega$ standard resistor, a volt box with a ratio of 20,000 to $20 \Omega$, a thermostated standard cell, and a Wolff Diesselhorst potentiometer. During the calibration experiments the calibration of the potentiometer was checked daily. Details on a similar calibration circuit are given by Churney and Armstrong [16]. The resistors, potentiometer, and standard cells were calibrated at the National Bureau of Standards.

\section{b. The Ignition System}

A high voltage coil was used for the igniter and the sparking was timed with an electric clock connected in the ignition circuit. The sparking power was measured in blank experiments to be $1.4 \mathrm{~J} \mathrm{sec}^{-1}$.

\section{c. Conduct of an Experiment}

Preliminary Actions. Before and after each experiment, the oxidizer-sample container, saturators, and magnesium perchlorate absorber (see figure 4) are weighed to $0.1 \mathrm{mg}$. In preparing the reaction vessel, the sparking lead is positioned over the flame position and demineralized water is added to the primary and secondary solution vessels and then the reaction vessel is assembled. The weight of the calorimeter can with water is adjusted to $5950 \pm 0.0005 \mathrm{~g}$ on a $6-\mathrm{kg}$ capacity balance. This weight also includes the support for the reaction vessel. Immediately the reaction vessel is positioned and the calorimeter is covered with its lid from which is suspended the calibration heater. Then the remaining assembly of the calorimeter and its accessories is completed.

Reactions. The three inlet flow lines are purged with helium to remove air and a flowing hydrogen atmosphere is established in the hydrogen inlets. The total flow rate of hydrogen varied, depending on the reaction being studied, from about 350 to $450 \mathrm{~cm}^{3}$ $\min ^{-1}$. Though the oxidizer line is initially flushed with helium, no gas is flowing through this line during the initial drift period. After a fore drift period of about $20 \mathrm{~min}$, during which time-temperature readings of the calorimeter are made, the reaction is initiated by simultaneously initiating the sparking and releasing gas from the sample bulb. The sparking is discontinued when there is certainty that the fuel has ignited. This is usually after 10 to 15 seconds of sparking. The increase in the rate of the temperature rise of the calorimeter and the decrease in the flow rate of effluent gas are the main signals that the reaction is taking place smoothly.

In most experiments, a $2.5-2.7 \mathrm{deg}$ temperature rise was achieved in a 15 - to 18 -minute reaction period. Near the end of the reaction period the oxidizer sample container is closed and the material remaining in the flow line is flushed into the burner with helium. The helium flow is reduced and continued for the remainder of the experiment while hydrogen flows through the other lines. After the reaction experiments the solution in the primary solution vessel is transferred, with washings, to a weighed $250-\mathrm{cm}^{3}$ polyethylene bottle. The secondary solution $\left(20 \mathrm{~cm}^{3}\right)$ is also recovered for titration.

Calibrations. The procedure for conducting the calibration experiments is similar to that used for the reactions. The solution vessels contain 100 and $20 \mathrm{~cm}^{3}$ water, respectively. A hydrogen flow through the bubblers is maintained at a rate comparable to that used for the reactions. The regulation of the helium flow in the oxidizer flow line constitutes the main difference between the gas handling procedures for the calibration and reaction experiments. In the calibrations a small flow of helium is maintained in the oxidizer line throughout the experiment, whereas for the reactions the helium flow is begun at the end of the reaction period.

\section{d. Calculations}

All of the values for the corrected temperature rise were calculated on an electronic computer with a computer program developed by Shomate [17]. For the calculation, it was necessary to give the computer the following data: (1) dial corrections for the Mueller bridge; (2) time and resistance readings taken during 
the reaction and drift periods of the experiment; and (3) constants for the platinum resistance thermometer. A comparison of some hand-calculated and computercalculated values showed that the program satisfactorily calculates the corrected resistance change, $\Delta R$ (corr); the initial and final drifts; the conversion factor, $\frac{d R}{d t}$; the initial and final temperatures for the reaction; the correction to the temperature rise, $\Delta t$ (corr); the corrected temperature rise, $\Delta t_{c}$; and the cooling constant.

The definition, $1 \mathrm{cal}=4.184 \mathrm{~J}$, was used for expressing the results in calories. All atomic weights were taken from the 1961 Table of Atomic Weights based on Carbon 12, adopted by the International Union of Pure and Applied Chemistry [18]. The heat capacity data used for the gases and liquid water are tabulated below. The heat of vaporization of water was taken as 2,439 and $2,428 \mathrm{~J} / \mathrm{g}$ at 298.15 and $303.15^{\circ} \mathrm{C}$, respectively [19]. Values for the heat capacity of aqueous hydrogen fluoride were obtained from the work of Thorvaldson and Bailey [20].

\begin{tabular}{|c|c|c|}
\hline Substance & $\begin{array}{c}C_{p 298.15} \\
\mathrm{~J} \mathrm{~mol}^{-1} \mathrm{deg}^{-1}\end{array}$ & Reference \\
\hline $\begin{array}{l}\mathrm{F}_{2}(\mathrm{~g}) \ldots \ldots \ldots \ldots \ldots \ldots \\
\mathrm{O}_{2}(\mathrm{~g}) \ldots \ldots \ldots \ldots \ldots \ldots \\
\mathrm{OF}_{2}(\mathrm{~g}) \ldots \ldots \ldots \ldots \ldots \\
\mathrm{H}_{2}(\mathrm{~g}) \ldots \ldots \ldots \ldots \ldots \ldots \\
\mathrm{H}_{2} \mathrm{O}(\mathrm{l}) \ldots \ldots \ldots \ldots \ldots\end{array}$ & $\begin{array}{l}31.30 \\
29.355 \\
43.30 \\
28.823 \\
75.2911\end{array}$ & $\begin{array}{l}{[8]} \\
{[8]} \\
{[8]} \\
{[8]} \\
{[8]}\end{array}$ \\
\hline
\end{tabular}

\section{e. Water Removal from the Reaction Vessel}

One general problem encountered in all the experiments was to account for and minimize loss of water from the reaction vessel. This was done by using a weighable drying tube on the outlet of the calorimeter and weighable saturators on the inlet tubes. The water entering and leaving the calorimeter could thus be monitored and the net change kept to a small value. The largest part of the residual heat effect due to condensation or evaporation could be presumed to form part of the causes of the initial and final drift rates, along with heat of stirring and heat transfer by conduction between the calorimeter and jacket. However, by keeping the net change in the amount of water small, it is believed that the uncertainty introduced by assuming the associated heat effects were constant would also be small. With this assumption, the results which are given in table 2 , do not require further discussion. However, it is interesting to note the consistency in the signs of the differences for a given set of experiments.

A net removal of water is observed for all of the calibration experiments. This is consistent with the use of the helium in the oxidizer line throughout the experiment. Because the helium is not passed through a saturator, it causes a removal of water from the reaction vessel. The signs in the changes of water in the reaction vessel during the reaction experiments nearly correlate with the amounts of excess hydrogen used. The stoichiometric and actually used reactant ratios are summarized below.

TABLE 2. Water changes in reaction vessel

\begin{tabular}{c|c|c|c}
\hline \hline & & Water removed \\
No. & $\mathrm{g}$ & $\begin{array}{c}\text { Water carried } \\
\text { in } \\
\mathrm{g}\end{array}$ & $\begin{array}{c}\text { Increase } \\
\mathrm{g}\end{array}$ \\
\hline
\end{tabular}

\begin{tabular}{|c|c|c|c|}
\hline \multicolumn{4}{|c|}{ Electrical calibrations } \\
\hline $\begin{array}{l}4 \\
5 \\
6 \\
7\end{array}$ & $\begin{array}{r}0.8033 \\
.8084 \\
.7025 \\
.7478\end{array}$ & $\begin{array}{r}0.5246 \\
.4813 \\
.4644 \\
.4637\end{array}$ & $\begin{array}{l}-0.2787 \\
-0.3271 \\
-0.2381 \\
-0.2841\end{array}$ \\
\hline \multicolumn{4}{|c|}{ Oxygen-hydrogen reaction } \\
\hline $\begin{array}{l}1 \\
2 \\
3 \\
4 \\
5 \\
6\end{array}$ & $\begin{array}{r}0.6680 \\
.6483 \\
.8313 \\
.8676 \\
.9486 \\
.9345\end{array}$ & $\begin{array}{r}0.6483 \\
.7264 \\
1.0051 \\
0.8887 \\
.9740 \\
.9461\end{array}$ & $\begin{array}{l}-0.0197 \\
+0.0781 \\
+0.1738 \\
+0.0211 \\
+0.0245 \\
+0.0116\end{array}$ \\
\hline \multicolumn{4}{|c|}{ Oxygen difluoride-hydrogen reaction } \\
\hline $\begin{array}{r}7 \\
8 \\
9 \\
10 \\
11\end{array}$ & $\begin{array}{r}0.5466 \\
.7458 \\
.7069 \\
.6102 \\
.5034\end{array}$ & $\begin{array}{r}0.5656 \\
.7135 \\
.7288 \\
.6805 \\
.6186\end{array}$ & $\begin{array}{l}+0.0190 \\
-0.0323 \\
+0.0219 \\
+0.0703 \\
+0.1152\end{array}$ \\
\hline \multicolumn{4}{|c|}{ Fluorine-hydrogen reaction } \\
\hline $\begin{array}{r}1 \\
2 \\
3 \\
5 \\
6 \\
7 \\
8 \\
9 \\
10\end{array}$ & $\begin{array}{l}1.4000 \\
1.2908 \\
1.1670 \\
0.9910 \\
1.0987 \\
0.8431 \\
1.0606 \\
0.9137 \\
.8322\end{array}$ & $\begin{array}{r}1.0715 \\
1.0127 \\
1.0396 \\
0.8310 \\
1.0397 \\
0.7853 \\
.9651 \\
.8323 \\
.7700\end{array}$ & $\begin{array}{l}-0.3285 \\
-0.2781 \\
-0.1274 \\
-0.1591 \\
-0.0590 \\
-0.0578 \\
-0.0955 \\
-0.0814 \\
-0.0622\end{array}$ \\
\hline \multicolumn{2}{|c|}{ reaction } & stoichiometric & actual \\
\hline $\begin{array}{c}\mathrm{O}_{2}-\mathrm{H}_{2} \\
\mathrm{~F}_{2}-\mathrm{H}_{2} \\
\mathrm{OF}_{2}-\mathrm{H}_{2}\end{array}$ & $\begin{array}{l}n_{\mathrm{H}_{2}} / n_{\mathrm{O}_{2}} \\
n_{\mathrm{H}_{2}} / n_{\mathrm{F}_{2}} \\
n_{\mathrm{H}_{2}} / n_{\mathrm{OF}_{2}}\end{array}$ & $\begin{array}{l}2 \\
1 \\
2\end{array}$ & $\begin{array}{c}2.8-3.4 \\
4 \\
4\end{array}$ \\
\hline
\end{tabular}

A much larger excess of hydrogen was used in the fluorine reactions. This shows in the net removal of water from the reaction vessel, compared to the deposition of water observed for the other reactions.

\section{Electrical Calibration Results}

A series of seven electrical calibration experiments was conducted and the data are given in table 3. Included in this table are the experiment number; the average calorimeter temperature, $t(\mathrm{av})$; the correction to the temperature rise, $\Delta t$ (corr); the corrected temperature rise, $\Delta t_{c}$; the average current; average voltage; heating time; electrical energy; and the energy equivalent of the calorimeter. For the seven experiments the average value for the energy equivalent was $21887.9 \mathrm{~J}\left({ }^{\circ} \mathrm{C}\right)^{-1}$ with a standard deviation of the mean of 0.006 percent. 
TABLE 3. Calibration of the calorimeter

\begin{tabular}{|c|c|c|c|c|c|c|c|}
\hline Expt. No. & 1 & 2 & 3 & 4 & 5 & 6 & 7 \\
\hline 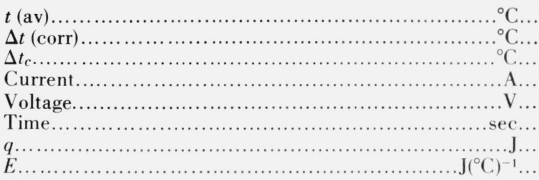 & $\begin{array}{l}30.37 \\
0.04724 \\
2.73616 \\
1.62580 \\
37.3949 \\
984.857 \\
59875.9 \\
21883.2\end{array}$ & $\begin{array}{l}30.36 \\
0.04976 \\
2.75413 \\
1.62770 \\
37.4378 \\
989.160 \\
60276.9 \\
21886.0\end{array}$ & $\begin{array}{l}30.38 \\
0.04658 \\
2.72360 \\
1.62706 \\
37.4236 \\
979.206 \\
59624.3 \\
21891.7\end{array}$ & $\begin{array}{l}30.39 \\
0.04332 \\
2.71066 \\
1.62711 \\
37.4280 \\
974.077 \\
59320.7 \\
21884.2\end{array}$ & $\begin{array}{l}30.37 \\
0.04878 \\
2.74159 \\
1.62770 \\
37.4385 \\
984.874 \\
60016.8 \\
21891.2\end{array}$ & $\begin{array}{c}30.38 \\
0.04709 \\
2.77289 \\
1.62817 \\
37.4483 \\
995.612 \\
60704.6 \\
21892.2\end{array}$ & $\begin{array}{c}30.48 \\
0.04368 \\
2.55693 \\
1.62737 \\
37.4282 \\
918.805 \\
55964.0 \\
21887.2\end{array}$ \\
\hline
\end{tabular}

\section{Examination of the Reaction Products}

The corrosivity of fluorine and hydrogen fluoride is a general problem to be minimized and checked in these experiments. This was partly accomplished by using Monel as the construction material for the flow line and combustion chamber. Prior to the experiments these parts of the flow system were exposed to a flowing fluorine atmosphere to condition the surfaces. Consequently, all of the fluorine released from the weighed sample bulb should enter into the reaction with hydrogen.

Most of the corrosion problem in these experiments was caused by the product hydrogen fluoride. The appearance of the combustion chamber after the experiments suggested that more corrosion resulted from the hydrogen fluoride in the $\mathrm{F}_{2}-\mathrm{H}_{2}$ reaction than from the $\mathrm{HF}-\mathrm{H}_{2} \mathrm{O}$ mixture in the $\mathrm{OF}_{2}-\mathrm{H}_{2}$ reaction.

The solutions and washings from the primary solution vessel were transferred to a weighed polyethylene bottle from which weighed aliquots were taken for titration with standard sodium hydroxide solution. After the analyses for $\mathrm{H}^{+}$, samples of these solutions were analyzed by atomic spectrophotometry for $\mathrm{Cu}^{++}$, $\mathrm{Ca}^{++}, \mathrm{Ni}^{++}$and $\mathrm{Ag}^{+}$. These results for the $\mathrm{F}_{2}-\mathrm{H}_{2}-\mathrm{H}_{2} \mathrm{O}$ and $\mathrm{OF}_{2}-\mathrm{H}_{2}-\mathrm{H}_{2} \mathrm{O}$ reactions are given in table 4 .

TABLE 4. Quantities of metal ions in hydrofluoric acid solutions

\begin{tabular}{|c|c|c|c|c|c|}
\hline Expt. No. & $\mathrm{Ag}$ & $\mathrm{Ca}$ & $\mathrm{Cu}$ & $\mathrm{Ni}$ & $n_{\mathrm{HF}}$ equiv \\
\hline & \multicolumn{4}{|c|}{$\mu$ moles } & (total) \\
\hline \multicolumn{6}{|c|}{$\mathrm{F}_{2}-\mathrm{H}_{2}-\mathrm{H}_{2} \mathrm{O}$ Reaction } \\
\hline $\begin{array}{r}1 \\
2 \\
3 \\
4 \\
5 \\
6 \\
7 \\
8 \\
9 \\
10\end{array}$ & $\begin{array}{l}<0.05 \\
<<.05 \\
<.05 \\
<.05 \\
<.05 \\
<.05 \\
<.05 \\
<.05 \\
<.05 \\
<.05\end{array}$ & $\begin{array}{l}<0.3 \\
<.3 \\
<.3 \\
<.3 \\
<.3 \\
<.3 \\
<.3 \\
<.3 \\
<.3 \\
<.3\end{array}$ & $\begin{array}{r}7.4 \\
9.0 \\
2.2 \\
1.5 \\
1.5 \\
3.2 \\
0.6 \\
<.1 \\
1.2 \\
3.5\end{array}$ & $\begin{array}{r}20.0 \\
16.1 \\
9.1 \\
3.9 \\
4.5 \\
8.4 \\
3.9 \\
4.7 \\
7.7 \\
10.0\end{array}$ & $\begin{array}{r}0.00005 \\
.00005 \\
.00003 \\
.00001 \\
.00001 \\
.00002 \\
.00001 \\
.00001 \\
.00002 \\
.00003\end{array}$ \\
\hline \multicolumn{6}{|c|}{$\mathrm{OF}_{2}-\mathrm{H}_{2}-\mathrm{H}_{2} \mathrm{O}$ Reaction } \\
\hline $\begin{array}{c}1 \\
4 \\
7 \\
\text { Blank }\end{array}$ & $\begin{aligned} & 0.3 \\
&< .05 \\
&< .05 \\
&<.05\end{aligned}$ & $\begin{array}{r}1.4 \\
0.9 \\
.9 \\
<.1\end{array}$ & $\begin{array}{r}16.1 \\
15.1 \\
16.8 \\
<0.1\end{array}$ & $\begin{array}{r}32.9 \\
23.4 \\
29.2 \\
<0.2\end{array}$ & $\begin{array}{r}0.00010 \\
.00008 \\
.00009\end{array}$ \\
\hline
\end{tabular}

For the fluorine reaction, the solution from each experiment was analyzed, and in the $\mathrm{OF}_{2}$ reaction solutions from three selected experiments were tested. The blank is a sample of the demineralized water used for the solutions. Because the blank showed no ions (outside the uncertainty intervals), we concluded that the metal ions resulted from the corrosion of the reaction vessel.

The total amount of corrosion cannot be determined from these tests. The total quantity of aqueous fluoride salts amounts to less than 10 percent of the deficiency of HF. (Compare $n_{\mathrm{HF}}$ (equiv) in table 4 with $\Delta n_{\mathrm{HF}}$ (obs-calc) in tables 7 and 9.) However, the tests do reveal some interesting features about the reactions.

The solutions from the fluorine reaction contain a smaller concentration of the metal ions, in spite of the more corroded appearance of the reaction vessel. It is possible that only the metal fluorides that exist in the vapor phase near the flame position are flushed downward by the effluent gas in this reaction. On the other hand, the product $\mathrm{HF}(\mathrm{aq})$ in the oxygen difluoride reaction may dissolve some metal fluorides and serve as a transport medium to the solution. Approximately $1 \mathrm{~g}$ of water was formed in each experiment, more than enough to wet the surfaces of the combustion chamber. Much more erosion of the $\mathrm{CaF}_{2}$ disk was observed for the $\mathrm{OF}_{2}$ reaction. This is consistent with the larger amount of $\mathrm{Ca}^{++}$present in the solution, and suggests that the $\mathrm{CaF}_{2}$ is slightly dissolved by the $\mathrm{HF}(\mathrm{aq})$, and then transferred to the solution.

\section{Reaction Heat Measurements}

\subsection{Oxygen-Hydrogen Reaction}

For six of the nine experiments on this reaction (series I) the contents of the calorimeter were the same as for the electrical calibrations. In the other three experiments (series II), the water in the solution vessel was omitted, so that the product water could be weighed and compared with the amount calculated from the weighed quantity of oxygen reacted. In these three experiments the water was flushed from the reaction vessel with helium and absorbed in magnesium perchlorate outside the calorimeter [21]. The data for the experiments are given in table 5 . $m_{s}$ is the mass of sample and $m_{0_{2}}$ is the mass of oxygen, based on the analysis given in section 2.l.b. $m_{\mathrm{H}_{2} \mathrm{O}}$ (obs) is the measured mass of water formed in the reaction and $m_{\mathrm{H}_{2} \mathrm{O}}(\mathrm{obs}) / m_{\mathrm{H}_{2} \mathrm{O}}(\mathrm{calc})$ is the ratio of the observed to calculated quantities of water. $t(\mathrm{av})$ is the average temperature of the calorimeter during the reaction and is the reference temperature for the reaction. $\Delta t$ (corr) and $\Delta t_{c}$ are respectively, the correction to the temperature rise and the corrected temperature rise. 
TABLE $5 . \quad \mathrm{O}_{2}-\mathrm{H}_{2}$ reaction

a. Heat measurements

\begin{tabular}{|c|c|c|c|c|c|c|c|c|c|}
\hline \multicolumn{7}{|c|}{ Series I } & \multicolumn{3}{|c|}{ Series II } \\
\hline Expt. No. & 1 & 2 & 3 & 4 & 5 & 6 & 7 & 8 & 9 \\
\hline 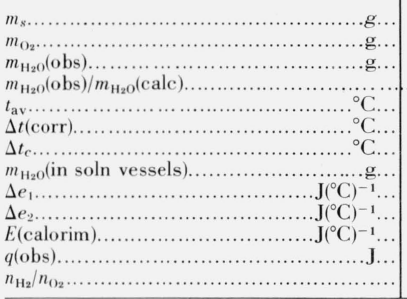 & $\begin{array}{l}30.36 \\
0.06586 \\
2.70570 \\
119.64 \\
7.8 \\
0 \\
21895.7 \\
59243.2 \\
2.81\end{array}$ & $\begin{array}{c}3.3850 \\
3.3846 \\
\mathrm{a} \\
\\
3 \ldots \ldots \ldots \\
30.38 \\
0.06620 \\
2.77304 \\
119.64 \\
7.5 \\
0 \\
21895.4 \\
60716.8 \\
2.88\end{array}$ & $\begin{array}{c}30.43 \\
0.05722 \\
2.86490 \\
119.64 \\
8.2 \\
0 \\
21896.1 \\
62730.1 \\
3.02\end{array}$ & $\begin{array}{l}30.31 \\
0.04966 \\
2.64052 \\
119.64 \\
7.6 \\
0 \\
21895.5 \\
57815.5 \\
3.35\end{array}$ & $\begin{array}{l}30.32 \\
0.05286 \\
2.64704 \\
119.64 \\
7.6 \\
0 \\
21895.5 \\
57958.3 \\
3.35\end{array}$ & $\begin{array}{c}30.32 \\
0.05159 \\
2.64914 \\
119.64 \\
7.6 \\
0 \\
21895.5 \\
58004.2 \\
3.23\end{array}$ & $\begin{array}{c}3.2342 \\
3.2338 \\
3.6417 \\
1.0001 \\
30.34 \\
0.07163 \\
2.67368 \\
0 \\
7.6 \\
-499.9 \\
21395.6 \\
57205.0 \\
2.96\end{array}$ & $\begin{array}{c}3.2325 \\
3.2321 \\
\mathrm{~b} \\
\\
30.34 \\
0.06773 \\
2.67882 \\
0 \\
7.6 \\
-499.9 \\
21395.6 \\
57315.0 \\
2.96\end{array}$ & $\begin{array}{c}3.1527 \\
3.1523 \\
3.5517 \\
1.0006 \\
30.37 \\
0.06378 \\
2.61481 \\
0 \\
7.4 \\
-499.9 \\
21395.4 \\
55944.9 \\
3.20\end{array}$ \\
\hline \multicolumn{10}{|c|}{ b. Corrections to the heat measurements } \\
\hline 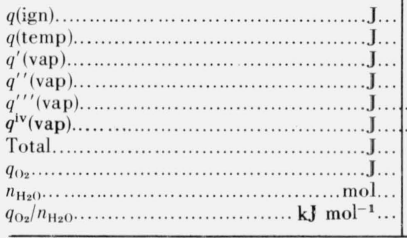 & $\begin{array}{c}293.5 \\
58949.7 \\
0.20644 \\
285.55\end{array}$ & $\begin{array}{c}293.4 \\
60423.4 \\
0.21154 \\
285.64\end{array}$ & $\begin{array}{c}386.6 \\
62343.5 \\
0.21838 \\
285.48\end{array}$ & $\begin{array}{c}260.4 \\
57555.1 \\
0.20128 \\
285.95\end{array}$ & $\begin{array}{c}300.0 \\
57658.3 \\
0.20154 \\
286.09\end{array}$ & $\begin{array}{c}270.7 \\
57733.5 \\
0.20234 \\
285.33\end{array}$ & $\begin{array}{c}16.4 \\
-18.4 \\
\ldots \ldots \ldots \ldots \\
\ldots \ldots \ldots \ldots \ldots \\
-366.9 \\
-33.9 \\
-402.8 \\
57607.8 \\
0.20212 \\
285.02\end{array}$ & $\begin{array}{c}10.5 \\
-46.4 \\
\ldots \ldots \ldots \ldots \\
\ldots \ldots \ldots \ldots \\
-227.6 \\
-33.8 \\
-297.3 \\
57612.3 \\
0.20202 \\
285.18\end{array}$ & $\begin{array}{c}17.1 \\
-38.5 \\
\ldots \ldots \ldots \ldots \\
\ldots \ldots \ldots \ldots \\
-181.6 \\
-33.8 \\
-236.8 \\
56181.7 \\
0.19702 \\
285.16\end{array}$ \\
\hline
\end{tabular}

${ }^{a}$ Water formed was not measured.

b Attempt to measure water was unsuccessful

$m_{\mathrm{H}_{2} \mathrm{O}}$ (in soln vessels) is the total mass of water in the solution vessels. $\Delta e_{1}$ is the correction to the energy equivalent for the water formed in the reaction (the heat capacity of half the water formed). $\Delta e_{2}$ is the correction for the omission of water from the solution vessel. $E$ (calorim) is the energy equivalent of the calorimeter corrected for the deviations from the standard calorimeter. $q(\mathrm{obs})$ is the observed heat effect.

$q($ ign) and $q$ (temp) correct for the ignition energy and the energy required to temper the reacting gases from room temperature to $t(\mathrm{av})$, the average calorimetric temperature during the reaction. $q(\mathrm{ign})$ was calculated from the sparking power, 1.4 $\mathrm{J} \mathrm{sec}^{-1}$ and the measured sparking times. $q($ temp) was calculated from the heat capacities and the measured amounts of the gases reacted.

$q^{\prime}$ (vap) is a correction for the addition of water to the reaction vessel during the reaction period by the reacting hydrogen. The hydrogen that enters into reaction is saturated with water, which condenses and is not carried out of the calorimeter. The amount of water added to the calorimeter is calculated from the volume of hydrogen reacted (based on stoichiometry of reaction) and the vapor pressure of water at the room temperature. $q^{\prime}$ (vap) is then the heat of condensation of this water at $t(\mathrm{av})$.

In contrast, the helium used for purging the oxidizer line causes a net removal of water from the solution vessel. We reason that if the gas flow were begun at the time when one-half of the temperature increase is achieved, no correction would be needed for the vaporization of the water because the heat effect would then be properly accounted for by the final drift rate measurements. $q^{\prime \prime}(\mathrm{vap})$ is a correction for the energy of vaporization of the additional water that would have been removed from the solution vessel had the helium flow been started at $t_{m}$ at the rate that was continued through the final drift period. $q^{\prime}(\operatorname{vap})$ and $q^{\prime \prime}($ vap) apply to all experiments with water in the solution vessel, whereas the corrections $q^{\prime \prime \prime}(\operatorname{vap})$ and $q^{\text {iv }}(\mathrm{vap})$ pertain only to the experiments in which the product water was measured. $q^{\prime \prime \prime}(\mathrm{vap})$ is the amount of heat required to vaporize the water removed from the reaction vessel by the hydrogen and helium during the reaction. This quantity of water was measured by weighing the absorber immediately after the experiment, and using another weighed absorber for collecting the water remaining in the reaction vessel. $q^{\mathrm{iv}}(\mathrm{vap})$ is the heat of vaporization of the water in the vapor phase in the reaction vessel.

We have assumed that the nitrogen impurity present in the hydrogen and the oxygen sample does not react and therefore no correction was applied. Under the conditions the nitrogen impurity may react to give $\mathrm{NH}_{3}$. No test was made for $\mathrm{NH}_{3}$ in these experiments. In similar calorimetric work Rossini [21] reported the presence of nitrogen in his oxygen sample. For some of his experiments in which oxygen was burned in a hydrogen atmosphere, he tested the product gases for $\mathrm{NH}_{3}$ and found the amount present to be negligibly small.

The heat of the oxygen-hydrogen reaction is given in table 6 . The values given represent averages for the number of experiments shown in parentheses. The data are given for $303.4^{\circ} \mathrm{K}$ and $298.15^{\circ} \mathrm{K}$. The factor, $\sigma$, is the standard deviation of the mean. As mentioned above, the series II measurements were conducted mainly for confirming the amount of reaction. Because water was not contained in the solution vessels for these measurements, we believe that the heat 
TABLE 6. Heat of the oxygen-hydrogen reaction

\begin{tabular}{|c|c|c|c|}
\hline \multicolumn{4}{|c|}{$\mathrm{H}_{2}(\mathrm{~g})+1 / 2 \mathrm{O}_{2}(\mathrm{~g})=\mathrm{H}_{2} \mathrm{O}(\mathrm{l})$} \\
\hline & $-\Delta H_{303.4}^{\circ}$ & $-\Delta H_{298,15}^{\circ}$ & $\sigma$ \\
\hline 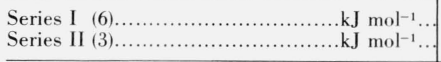 & $\begin{array}{l}285.67 \\
285.12\end{array}$ & $\begin{array}{l}285.84 \\
284.30\end{array}$ & $\begin{array}{r}0.12 \\
\ldots \ldots+\cdots\end{array}$ \\
\hline 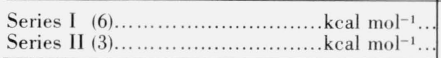 & $\begin{array}{l}68.28 \\
68.14\end{array}$ & $\begin{array}{l}68.32 \\
68.18\end{array}$ & 0.03 \\
\hline
\end{tabular}

$\sigma$ is the standard deviation of the mean

data are less reliable than the series I data. The fact that they are less negative suggests that all of the heat from the reaction was not dissipated by the effluent gas. We do not propose the value found here, $\Delta \mathrm{H}_{298.15}^{\circ}$ $=-68.32 \mathrm{kcal} \mathrm{mol}^{-1}$, as a replacement for Rossini's determination [21], but use the agreement with the earlier work as an indication of the general validity of these and other experiments conducted in this study.

\subsection{Fluorine-Hydrogen-Water Reaction}

Ten experiments were conducted for the $\mathrm{F}_{2}-\mathrm{H}_{2}-\mathrm{H}_{2} \mathrm{O}$ reaction. For the first five experiments only the oxidizer flow line was conditioned with fluorine, whereas in the remaining experiments the flow line and com- bustion chamber were conditioned. On this basis the data for the experiments are presented in two series.

The data for these experiments are given in table 7 . The heat measurement data have been explained for the oxygen reaction. $\Delta e$ is a correction to the energy equivalent for the hydrogen fluoride formed in the reaction (one half the heat capacity of the hydrogen fluoride). $n_{\mathrm{H}_{2} \mathrm{O}} / n_{\mathrm{HF}}$ is the ratio of the moles water in the solution vessel to the moles of hydrogen fluoride formed in the reaction, as determined by the analyses of the solutions.

For the reaction quantities, $n_{\mathrm{HF}}\left(\mathrm{F}_{2}\right)$ and $n_{\mathrm{HF}}\left(\mathrm{CF}_{4}\right)$ are the numbers of moles of $\mathrm{HF}$ produced from $\mathrm{F}_{2}$ and $\mathrm{CF}_{4}$, respectively. They were calculated from the analyses in table 1 . The deficiency of HF in these experiments varied greatly. For the ten experiments, the values of $n_{\mathrm{HF}}(\mathrm{obs}) / n_{\mathrm{HF}}($ calc $)$ ranged from 0.9772 to 0.9964 , with a mean of 0.9844 . We assume that the deficiency of HF is caused by corrosion. However, the erraticity of the recovery is difficult to explain.

The ignition, vaporization, and gas temperature corrections are the same as described above. $q_{\mathrm{O}_{2}}$, $q_{\mathrm{CF}_{4}}$, and $q_{\mathrm{CO}_{2}}$ are corrections for the reactions of the impurities. These corrections were calculated on the basis of eqs (1), (2), and (3).

$$
\Delta H_{R, 298.15}{ }^{\circ} \mathrm{K} \quad[8]
$$

$$
\begin{array}{cc}
\mathrm{H}_{2}(\mathrm{~g})+{ }^{1 / 2} \mathrm{O}_{2}(\mathrm{~g}) \rightarrow \mathrm{H}_{2} \mathrm{O}(\mathrm{l}) & -68.32 \mathrm{kcal}\left(\mathrm{mol} \mathrm{H}_{2} \mathrm{O}\right)^{-1} \\
2 \mathrm{H}_{2}(\mathrm{~g})+\mathrm{CF}_{4}(\mathrm{~g})+50 \mathrm{H}_{2}(\mathrm{l}) \rightarrow 4\left[\mathrm{HF}: 50 \mathrm{H}_{2} \mathrm{O}\right](\mathrm{l})+\mathrm{C}(\mathrm{c}) & -84.2 \mathrm{kcal}\left(\mathrm{mol} \mathrm{CF}_{4}\right)^{-1} \\
2 \mathrm{H}_{2}(\mathrm{~g})+\mathrm{CO}_{2}(\mathrm{~g}) \rightarrow \mathrm{C}(\mathrm{c})+2 \mathrm{H}_{2} \mathrm{O}(\mathrm{l}) & -42.59 \mathrm{kcal}\left(\mathrm{mol} \mathrm{CO}_{2}\right)^{-1}
\end{array}
$$

\begin{tabular}{|c|c|c|c|c|c|c|c|c|c|c|}
\hline \multirow[b]{2}{*}{ Expt. No. } & \multicolumn{5}{|c|}{ Series 1} & \multicolumn{5}{|c|}{ Series 2} \\
\hline & 1 & 2 & 3 & 4 & 5 & 6 & 7 & 8 & 9 & 10 \\
\hline 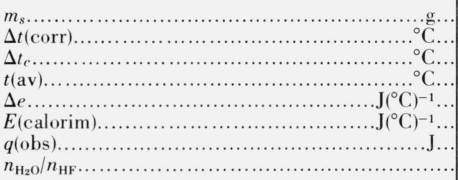 & $\begin{array}{l}3.5504 \\
0.05552 \\
2.71469 \\
30.35 \\
1.8 \\
21889.7 \\
59423.7 \\
30.4\end{array}$ & $\begin{array}{l}2.7483 \\
0.03351 \\
2.10439 \\
30.73 \\
1.4 \\
21889.3 \\
46063.6 \\
38.9\end{array}$ & $\begin{array}{l}2.7084 \\
0.03381 \\
2.07278 \\
30.73 \\
1.4 \\
21889.3 \\
45371.7 \\
39.8\end{array}$ & $\begin{array}{l}1.3165 \\
0.07354 \\
1.01125 \\
30.02 \\
1.0 \\
21888.9 \\
22135.2 \\
82.9\end{array}$ & $\begin{array}{l}2.7981 \\
0.02279 \\
2.14415 \\
30.74 \\
1.4 \\
21889.3 \\
46933.9 \\
38.2\end{array}$ & $\begin{array}{l}2.9859 \\
0.07565 \\
2.29429 \\
30.16 \\
1.6 \\
21889.5 \\
50220.9 \\
35.8\end{array}$ & $\begin{array}{l}2.4623 \\
0.02937 \\
1.89230 \\
30.78 \\
1.6 \\
21889.5 \\
41421.5 \\
44.3\end{array}$ & $\begin{array}{c}2.6524 \\
0.03237 \\
2.04004 \\
30.69 \\
1.4 \\
21889.3 \\
44655.0 \\
40.9\end{array}$ & $\begin{array}{c}3.1136 \\
0.04481 \\
2.39349 \\
30.51 \\
1.6 \\
21889.5 \\
52392.3 \\
34.8\end{array}$ & $\begin{array}{c}2.4048 \\
0.05046 \\
2.61824 \\
30.30 \\
1.8 \\
21889.7 \\
57312.5 \\
31.8\end{array}$ \\
\hline \multicolumn{11}{|c|}{ b. Reaction quantities } \\
\hline 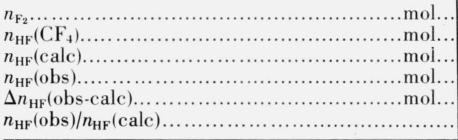 & $\begin{array}{c}0.09243 \\
.00020 \\
.18506 \\
.18277 \\
-.00229 \\
.9876\end{array}$ & $\begin{array}{r}0.07155 \\
.00016 \\
.14326 \\
.14267 \\
-.00059 \\
.9959\end{array}$ & $\begin{array}{r}0.07051 \\
.00016 \\
.14118 \\
.13965 \\
-.00153 \\
.9891\end{array}$ & $\begin{array}{c}0.03427 \\
.00008 \\
.06862 \\
.06706 \\
-.00156 \\
.9772\end{array}$ & $\begin{array}{c}0.07284 \\
.00016 \\
.14584 \\
.14532 \\
-.00052 \\
.9964\end{array}$ & $\begin{array}{r}0.07773 \\
.00016 \\
.15562 \\
.15502 \\
-.00060 \\
.9961\end{array}$ & $\begin{array}{r}0.06410 \\
.00012 \\
.12832 \\
.12545 \\
-.00282 \\
.9776\end{array}$ & $\begin{array}{r}0.06905 \\
.00016 \\
.13826 \\
.13596 \\
-.00230 \\
.9833\end{array}$ & $\begin{array}{c}0.08111 \\
.00016 \\
.16238 \\
.15938 \\
-.00300 \\
.9815\end{array}$ & $\begin{array}{c}0.08864 \\
.00020 \\
.17748 \\
.17453 \\
-.00295 \\
.9833\end{array}$ \\
\hline \multicolumn{11}{|c|}{ c. Corrections to heat data } \\
\hline 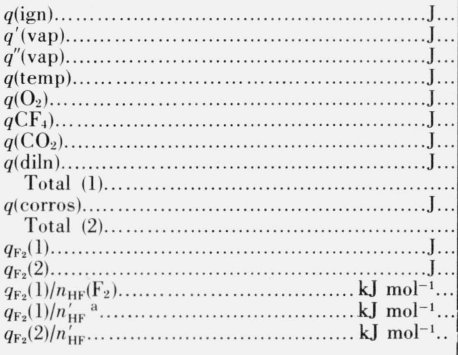 & $\begin{array}{r}17.6 \\
122.6 \\
31.4 \\
-15.5 \\
205.8 \\
17.6 \\
1.7 \\
-12.2 \\
369.0 \\
764 . \\
1133.0 \\
59054.7 \\
58290.7 \\
319.45 \\
323.46 \\
319.28\end{array}$ & $\begin{array}{r}30.0 \\
100.3 \\
24.3 \\
-7.3 \\
159.8 \\
14.1 \\
1.7 \\
-6.5 \\
306.4 \\
197 . \\
503.4 \\
45757.2 \\
45560.2 \\
319.76 \\
321.08 \\
319.70\end{array}$ & $\begin{array}{r}14.8 \\
100.3 \\
25.5 \\
-13.8 \\
159.8 \\
14.1 \\
1.7 \\
-5.3 \\
297.1 \\
510 . \\
807.1 \\
45074.6 \\
44564.6 \\
319.63 \\
323.14 \\
319.48\end{array}$ & $\begin{array}{r}19.6 \\
56.9 \\
14.2 \\
-1.5 \\
74.0 \\
6.7 \\
.8 \\
7.0 \\
163.7 \\
520 . \\
683.7 \\
21957.5 \\
21437.5 \\
320.36 \\
327.82 \\
320.06\end{array}$ & $\begin{array}{r}23.2 \\
90.8 \\
22.4 \\
-25.1 \\
165.7 \\
14.1 \\
1.7 \\
-6.1 \\
286.7 \\
173 . \\
459.7 \\
46647.2 \\
46474.2 \\
320.20 \\
321.35 \\
320.16\end{array}$ & $\begin{array}{r}22.4 \\
120.9 \\
26.3 \\
-11.1 \\
177.0 \\
14.1 \\
1.7 \\
-7.1 \\
344.2 \\
200 . \\
544.2 \\
49876.7 \\
49676 . \\
320.83 \\
322.08 \\
320.78\end{array}$ & $\begin{array}{r}19.0 \\
89.9 \\
21.4 \\
-15.5 \\
142.0 \\
10.5 \\
1.7 \\
-1.0 \\
268.0 \\
958 . \\
1226.0 \\
41153.5 \\
40195.5 \\
321.01 \\
328.36 \\
320.72\end{array}$ & $\begin{array}{r}23.8 \\
95.8 \\
21.3 \\
-14.6 \\
154.4 \\
14.4 \\
1.7 \\
-3.4 \\
293.4 \\
767 . \\
1060.4 \\
44361.6 \\
43594.6 \\
321.23 \\
326.67 \\
321.02\end{array}$ & $\begin{array}{r}30.2 \\
109.2 \\
25.1 \\
-19.2 \\
182.8 \\
14.1 \\
1.7 \\
-8.0 \\
335.9 \\
1001 . \\
1336.9 \\
52056.4 \\
51055.4 \\
320.90 \\
326.95 \\
320.66\end{array}$ & $\begin{array}{r}24.1 \\
104.0 \\
30.7 \\
-34.9 \\
200.0 \\
17.6 \\
1.7 \\
-11.7 \\
331.5 \\
984 . \\
1315.6 \\
56981.0 \\
55997.0 \\
321.42 \\
326.86 \\
321.21\end{array}$ \\
\hline
\end{tabular}

TABLE 7. $\mathrm{F}_{2}-\mathrm{H}_{2}-\mathrm{H}_{2} \mathrm{O}$ reaction 
$q($ diln ) corrects for diluting the acid solution from a concentration, $\mathrm{HF}: n \mathrm{H}_{2} \mathrm{O}$, to $\mathrm{HF}: 50 \mathrm{H}_{2} \mathrm{O}$. Total (1) is the sum of the corrections to this point and total (2) includes $q$ (corros), a correction for the corrosion of the combustion chamber. Equation (4) is the corrosion reaction assumed and shows the heat of reaction used for calculating $q(\operatorname{corros})[22]$. The number of moles of reaction (4) is taken to be $n_{\mathrm{HF}}($ obs-calc) $/ 2$.

$\mathrm{F}_{2}(\mathrm{~g})+\mathrm{Ni}(\mathrm{c}) \rightarrow \mathrm{NiF}_{2}(\mathrm{c}) \quad-159.5 \mathrm{kcal}\left(\mathrm{mol} \mathrm{F}_{2_{4}}{ }^{-1}\right.$

The corrections Total (1) and Total (2), table 7, were applied to the observed heat effect to give $q_{\mathrm{F}_{2}}(1)$ and $q_{\mathrm{F} 2}(2)$, respectively. We now have three ways of calculating the results. Referring to experiment (1) for example, in the first way the heat of reaction corrected by Total (1) to give $q_{\mathrm{F}_{2}}^{(1)}$ is presumed to be caused by the measured amount of $\mathrm{F}_{2}$ introduced, giving $q_{\mathrm{F}_{2}}(1) / n_{\mathrm{HF}}\left(\mathrm{F}_{2}\right)=319.45 \mathrm{~kJ} \mathrm{~mol}^{-1}$. In the second way the same heat of reaction is attributed to reaction of enough fluorine to form the observed amount of $\mathrm{HF}$, giving $q_{\mathrm{F}_{2}}(\mathrm{l}) / n_{\mathrm{HF}}^{\prime}=323.46$ $\mathrm{kJ} \mathrm{mol}^{-1}$. In the third way the deficiency of $\mathrm{HF}$ is attributed to corrosion forming $\mathrm{NiF}_{2}(\mathrm{c})$, introducing an additional energy correction, $q$ (corros), and allowing a new total energy, $q_{\mathrm{F}_{2}}(2)$ to be attributed to the amount of $F_{2}$ needed to form the observed HF. This gives $q_{\mathrm{F}^{2}}(2) / n_{\mathrm{HF}}^{\prime}=319.28 \mathrm{~kJ} \mathrm{~mol}^{-1}$, which we consider to be the best representation of the data. All experiments are treated each way at the bottom of table 7 .
The results of two series of five measurements each are summarized in table 8 in which the results obtained by the three methods are listed in columns (1), (2), and (3), respectively. The calculation in column (3) is preferred for reasons described above and experiments of series 2 are considered to be preferable because of a better conditioning procedure for the reaction vessel. Hence, the value $\Delta H_{303}^{\circ}=-76.69$ kcal $\mathrm{mol}^{-1}$ is selected for use in later calculations. This value, corrected to $298.15^{\circ}$ gives

$$
\Delta H_{f 298.15}^{\circ}\left[\mathrm{HF} \cdot 50 \mathrm{H}_{2} \mathrm{O}\right]=-76.68 \mathrm{kcal} \mathrm{mol}{ }^{-1} .
$$

TABLE 8. Heat of fluorine-hydrogen-water reaction

\begin{tabular}{|c|c|c|c|c|c|c|}
\hline \multicolumn{7}{|c|}{$1 / 2 \mathrm{~F}_{2}(\mathrm{~g})+1 / 2 \mathrm{H}_{2}(\mathrm{~g})+50 \mathrm{H}_{2} \mathrm{O}(\mathrm{l})=\left[\mathrm{HF} \cdot 50 \mathrm{H}_{2} \mathrm{O}\right](\mathrm{l})$} \\
\hline & (1) & & (2) & & (3) & \\
\hline & $-\Delta H_{303}^{\circ}$ & $\sigma$ & $-\Delta H_{303}^{\circ}$ & $\sigma$ & $-\Delta H_{303}^{\circ}$ & $\sigma$ \\
\hline Series 1 (5)... & 319.88 & 0.17 & 323.37 & 1.21 & 319.74 & 0.15 \\
\hline Series $2(5) \ldots . .$. & 321.08 & 0.11 & 326.18 & 1.07 & 320.87 & 0.11 \\
\hline Series $1(5) \ldots \ldots . . . \mathrm{kcal} \mathrm{mol} l^{-1} \ldots$ & 76.45 & 0.04 & 77.29 & 0.29 & 76.42 & 0.04 \\
\hline Series 2 (5)..........kal mol-1... & 76.74 & 0.03 & 77.96 & 0.25 & 76.69 & 0.03 \\
\hline
\end{tabular}

$\sigma$ is the standard deviation of the mean.

\subsection{The $\mathrm{OF}_{2}-\mathrm{Hydrogen}_{\text {Water Reaction }}$}

The data obtained for this reaction are shown in table 9. No new features are involved. The experiments in series 1 were conducted before the electrical cali-

TABLE 9. $\mathrm{OF}_{2}-\mathrm{H}_{2}-\mathrm{H}_{2} \mathrm{O}$ reaction

\begin{tabular}{|c|c|c|c|c|c|c|c|c|c|c|c|c|c|}
\hline \multirow[b]{2}{*}{ Expt. No. } & \multicolumn{6}{|c|}{ Series 1} & \multicolumn{7}{|c|}{ Series 2} \\
\hline & 1 & 2 & 3 & 4 & 5 & 6 & 7 & 8 & 9 & 10 & 11 & 12 & 13 \\
\hline 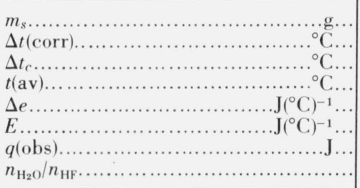 & $\begin{array}{l}2.9080 \\
0.05253 \\
2.34591 \\
30.16 \\
3.8 \\
21891.7 \\
51356.0 \\
52.6\end{array}$ & $\begin{array}{c}3.4370 \\
0.04624 \\
2.77485 \\
30.37 \\
4.0 \\
21891.9 \\
60746.7 \\
44.6\end{array}$ & $\begin{array}{l}3.0869 \\
0.05224 \\
2.49106 \\
30.25 \\
3.9 \\
21891.8 \\
54533.8 \\
49.4\end{array}$ & $\begin{array}{l}3.5261 \\
0.04464 \\
2.84661 \\
30.41 \\
4.0 \\
21891.9 \\
62317.7 \\
43.2\end{array}$ & $\begin{array}{l}3.4556 \\
0.05456 \\
2.78877 \\
30.38 \\
3.9 \\
21891.8 \\
61051.2 \\
44.3\end{array}$ & $\begin{array}{l}3.4512 \\
0.05402 \\
2.78491 \\
30.38 \\
3.9 \\
21891.8 \\
60966.7 \\
44.4\end{array}$ & $\begin{array}{l}3.4558 \\
0.05216 \\
2.78889 \\
30.39 \\
3.9 \\
21891.8 \\
61053.8 \\
44.4\end{array}$ & $\begin{array}{l}3.4015 \\
0.05179 \\
2.74369 \\
30.37 \\
3.9 \\
21891.8 \\
60064.3 \\
45.1\end{array}$ & $\begin{array}{l}3.3549 \\
0.05348 \\
2.70657 \\
30.37 \\
3.9 \\
21891.8 \\
59251.7 \\
45.8\end{array}$ & $\begin{array}{c}3.3785 \\
0.05228 \\
2.72699 \\
30.36 \\
3.9 \\
21891.8 \\
59698.7 \\
45.5\end{array}$ & $\begin{array}{c}3.4021 \\
0.04842 \\
2.74267 \\
30.50 \\
3.9 \\
21891.8 \\
60042.0 \\
45.3\end{array}$ & $\begin{array}{c}3.4929 \\
0.04621 \\
2.81633 \\
30.45 \\
4.0 \\
21891.9 \\
61654.8 \\
43.8\end{array}$ & $\begin{array}{c}3.4651 \\
0.04681 \\
2.79548 \\
30.42 \\
4.0 \\
21891.9 \\
61198.4 \\
44.3\end{array}$ \\
\hline \multicolumn{14}{|c|}{ b. Reaction quantities } \\
\hline 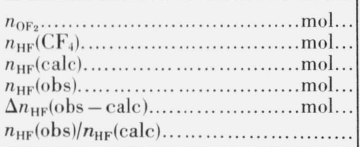 & $\begin{array}{r}0.05351 \\
.00016 \\
.10718 \\
.10669 \\
-.00049 \\
.9954\end{array}$ & $\begin{array}{r}0.06224 \\
.00016 \\
.12664 \\
.12602 \\
-.00062 \\
.9951\end{array}$ & $\begin{array}{r}0.05680 \\
.00016 \\
.11376 \\
.11380 \\
+.00004 \\
1.0003\end{array}$ & $\begin{array}{r}0.06488 \\
.00016 \\
.12992 \\
.13009 \\
+.00017 \\
1.0013\end{array}$ & $\begin{array}{r}0.06359 \\
.00016 \\
.12734 \\
.12682 \\
-.00052 \\
.9959\end{array}$ & $\begin{array}{r}0.06351 \\
.00016 \\
.12718 \\
.12634 \\
-.00084 \\
.9934\end{array}$ & $\begin{array}{r}0.06359 \\
.00016 \\
.12734 \\
.12658 \\
-.00076 \\
.9940\end{array}$ & $\begin{array}{r}0.06259 \\
.00016 \\
.12534 \\
.12462 \\
-.00072 \\
.9942\end{array}$ & $\begin{array}{r}0.06173 \\
.00016 \\
.12362 \\
.12266 \\
-.00096 \\
.9922\end{array}$ & $\begin{array}{l}0.06217 \\
.00016 \\
.12450 \\
.12355 \\
.00095 \\
.9924\end{array}$ & $\begin{array}{r}0.06260 \\
.00016 \\
.12536 \\
.12399 \\
-.00137 \\
.9890\end{array}$ & $\begin{array}{r}0.06427 \\
.00016 \\
.12870 \\
.12811 \\
-.00059 \\
.9954\end{array}$ & $\begin{array}{r}0.06376 \\
.00016 \\
.12768 \\
.12686 \\
-.00082 \\
.9936\end{array}$ \\
\hline \multicolumn{14}{|c|}{ c. Corrections to heat measurements } \\
\hline 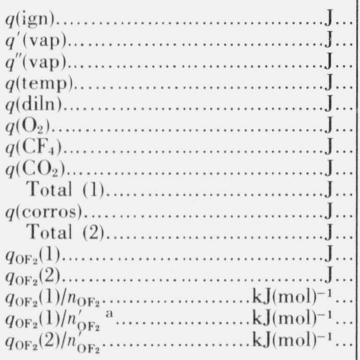 & $\begin{array}{r}17.1 \\
140.6 \\
31.8 \\
-22.8 \\
+1.8 \\
234.3 \\
14.1 \\
8.8 \\
425.7 \\
240 . \\
665.7 \\
50930.2 \\
50690.2 \\
951.79 \\
956.17 \\
951.66\end{array}$ & $\begin{array}{r}18.9 \\
155.0 \\
55.6 \\
-36.8 \\
-1.0 \\
274.0 \\
14.1 \\
10.5 \\
490.3 \\
303 . \\
793.3 \\
60256.4 \\
59953.4 \\
952.82 \\
957.51 \\
952.70\end{array}$ & $\begin{array}{r}19.3 \\
130.9 \\
43.6 \\
-30.1 \\
-.4 \\
245.6 \\
14.1 \\
10.5 \\
433.5 \\
0 \\
433.5 \\
54100.2 \\
54100.2 \\
952.47 \\
952.13 \\
952.13\end{array}$ & $\begin{array}{r}14.0 \\
162.7 \\
45.2 \\
-35.6 \\
-2.2 \\
285.8 \\
14.1 \\
10.5 \\
494.5 \\
0 \\
494.5 \\
61823.2 \\
61823.2 \\
952.88 \\
951.71 \\
951.71\end{array}$ & $\begin{array}{r}21.6 \\
179.1 \\
53.1 \\
-22.0 \\
-1.0 \\
274.0 \\
14.1 \\
10.5 \\
529.4 \\
254 . \\
783.4 \\
60521.7 \\
60267.7 \\
951.75 \\
955.66 \\
951.64\end{array}$ & $\begin{array}{r}21.6 \\
169.4 \\
53.1 \\
-28.4 \\
-1.0 \\
274.0 \\
14.1 \\
10.5 \\
513.3 \\
411 . \\
924.3 \\
60453.4 \\
60042.4 \\
951.87 \\
958.21 \\
951.69\end{array}$ & $\begin{array}{r}16.8 \\
148.1 \\
53.1 \\
-38.2 \\
-1.0 \\
274.0 \\
14.1 \\
10.5 \\
477.4 \\
372 . \\
849.4 \\
60576.4 \\
60204.4 \\
952.61 \\
958.33 \\
952.45\end{array}$ & $\begin{array}{r}19.6 \\
146.1 \\
45.2 \\
-42.0 \\
-.5 \\
274.0 \\
14.1 \\
10.5 \\
467.0 \\
352 . \\
819.0 \\
59597.3 \\
59245.3 \\
952.18 \\
957.69 \\
952.04\end{array}$ & $\begin{array}{r}18.5 \\
143.9 \\
50.6 \\
-40.2 \\
-.5 \\
268.6 \\
14.1 \\
10.5 \\
465.5 \\
469 . \\
934.5 \\
58786.2 \\
58317.2 \\
952.31 \\
959.77 \\
952.12\end{array}$ & $\begin{array}{r}14.8 \\
154.8 \\
50.6 \\
-34.2 \\
-.5 \\
268.6 \\
14.1 \\
10.5 \\
478.7 \\
465 . \\
943.7 \\
59220.0 \\
58755.0 \\
952.55 \\
959.96 \\
952.35\end{array}$ & $\begin{array}{r}14.8 \\
165.7 \\
49.8 \\
-29.3 \\
-.5 \\
268.6 \\
14.1 \\
10.5 \\
493.7 \\
670 . \\
1163.7 \\
59548.2 \\
58878.2 \\
951.25 \\
961.85 \\
951.03\end{array}$ & $\begin{array}{r}19.0 \\
156.9 \\
50.6 \\
-37.0 \\
-1.0 \\
279.9 \\
14.1 \\
10.5 \\
493.0 \\
288 . \\
781.0 \\
61161.8 \\
60873.8 \\
951.64 \\
956.10 \\
951.52\end{array}$ & $\begin{array}{r}19.9 \\
148.1 \\
50.6 \\
-41.5 \\
-1.0 \\
279.9 \\
14.1 \\
10.5 \\
480.6 \\
401 . \\
881.6 \\
60717.8 \\
60316.8 \\
952.29 \\
958.45 \\
952.12\end{array}$ \\
\hline
\end{tabular}

${ }^{\mathrm{a}} n_{\mathrm{OF}_{2}}^{\prime}=\left[n_{\mathrm{HF}}(\mathrm{obs})-n_{\mathrm{HF}}\left(\mathrm{CF}_{4}\right)\right] / 2$. 
brations were performed, and those in series 2 were conducted later. Otherwise, the procedures used were identical. The average recovery of hydrogen fluoride was better than 99.5 percent. $q$ (corros) for this system was calculated from eq (5) using the heat of reaction given there and a number of moles equal to $\Delta n_{\mathrm{HF}}$ (obscalc)/2.

$$
\begin{aligned}
\mathrm{OF}_{2}(\mathrm{~g})+\mathrm{Ni}(\mathrm{c})+\mathrm{H}_{2}(\mathrm{~g}) & =\mathrm{H}_{2} \mathrm{O}(\mathrm{l})+\mathrm{NiF}_{2}(\mathrm{c}) \\
& -233.78 \mathrm{kcal}\left(\mathrm{mol} \mathrm{OF}_{2}\right)^{-1}
\end{aligned}
$$

The treatment is the same as for the fluorine reaction. The three alternative calculations of the reaction energy are shown at the bottom of table 9 and in table 10 , of which the preferred one is based upon the amount of energy, adjusted for the energy of corrosion, and the amount of hydrogen fluoride actually observed. This is given as $\Delta H_{303}^{\circ}(3)$ of table 10 .

\begin{tabular}{|c|c|c|c|c|c|c|}
\hline \multicolumn{7}{|c|}{$\mathrm{OF}_{2}+2 \mathrm{H}_{2}+99 \mathrm{H}_{2} \mathrm{O}=2\left[\mathrm{HF} \cdot 50 \mathrm{H}_{2} \mathrm{O}\right](l)$} \\
\hline & $-\Delta H_{303}^{\circ}(1)$ & $\sigma$ & $-\Delta H_{303}^{\circ}(2)$ & $\sigma$ & $-\Delta H_{303}^{\circ}(3)$ & $\sigma$ \\
\hline $\begin{array}{l}\text { Series } 1 \ldots . . . \mathrm{kJ} \mathrm{mol}^{-1} \ldots \\
\text { Series } 2 \ldots \ldots \mathrm{kJ} \mathrm{mol}{ }^{-1} \ldots \\
\text { Total }(13 \text { expts) } \ldots \ldots \ldots . . .\end{array}$ & $\begin{array}{l}952.26 \\
952.12 \\
952.18\end{array}$ & 0.14 & $\begin{array}{l}955.23 \\
958.88 \\
957.20\end{array}$ & 0.80 & $\begin{array}{l}951.92 \\
951.95 \\
951.94\end{array}$ & 0.14 \\
\hline $\begin{array}{l}\text { Series } 1 \\
\quad \text { kcal mol } \\
\text { Series } 2 \\
\quad \text { kcal mol } \\
\text { Total }(13 \text { expts }) \ldots \ldots \ldots . .\end{array}$ & 227.60 & 0.033 & $\begin{array}{l}229.18 \\
228.78\end{array}$ & 0.19 & 227.51 & 0.033 \\
\hline
\end{tabular}

TABLE 10. Heat of $\mathrm{OF}_{2}-\mathrm{H}_{2}-\mathrm{H}_{2} \mathrm{O}$ reaction

$\sigma$ is the standard deviation of the mean.

\section{Discussion of Errors}

The uncertainties are summarized in table 11 for the three reactions and for the calculation of the heat of formation of $\mathrm{OF}_{2}(\mathrm{~g})$. The observed standard deviation of the $\mathrm{OF}_{2}-\mathrm{H}_{2}-\mathrm{H}_{2} \mathrm{O}$ measurements is $0.14 \mathrm{~kJ} \mathrm{~mol}^{-1}$ or
0.015 percent and that for the electrical calibrations is 0.015 percent. Hence the overall imprecision in the experiments expressed in 2-sigma limits is

$$
\begin{aligned}
& \pm 2 \sqrt{(0.015)^{2}+(0.015)^{2}} \\
& = \pm 0.042 \text { percent }\left(0.40 \mathrm{~kJ} \mathrm{~mol}^{-1}\right)
\end{aligned}
$$

Systematic errors in calibration are 0.02 percent for "irrelevance" and 0.02 percent for the transient. Systematic errors in the reaction heat measurements are 0.02 percent for uncertainty in the oxygen content of the sample, and 0.02 percent for uncertainty in the correction for corrosion. Each of these sources of error is explained below. Assuming that these errors are independent we apply them as the square root of the sum of the squares and obtain 0.040 percent $\left(0.38 \mathrm{~kJ} \mathrm{~mol}^{-1}\right)$ as the overall systematic error. The overall uncertainty in the heat of reaction is, therefore the sum of 0.042 and 0.040 or 0.082 percent $\left(0.78 \mathrm{~kJ} \mathrm{~mol}^{-1}\right.$ or $\left.0.19 \mathrm{kcal} \mathrm{mol}^{-1}\right)$.

The error treatments for the two other reactions are summarized in much the same way. The systematic errors for the $\mathrm{O}_{2}-\mathrm{H}_{2}$ experiments do not include any uncertainties for analysis or corrosion, but do include systematic errors listed for the calibration. To place these on the same basis as the other calculations, we combine these two systematic errors as the square root of the sum of the squares.

In estimating the uncertainty in the heat of formation of $\mathrm{OF}_{2}$ we combine the contributions in joules for the three reactions in the following way. The random errors and the chemical errors, which are presumed to be independent for the various reactions, are added without regard to sign; and the systematic calibration errors are added with due regard for the sign with which the reaction equations are added, in order to

\begin{tabular}{|c|c|c|c|c|c|c|c|}
\hline$\Delta H_{R} 303{ }^{\circ} \mathrm{K} \mathrm{kJ} \mathrm{mol}^{-1}$ & \multicolumn{2}{|c|}{951.94} & \multicolumn{2}{|c|}{320.88} & \multicolumn{2}{|c|}{285.67} & \\
\hline & \multicolumn{2}{|c|}{$\mathrm{OF}_{2} \cdot \mathrm{H}_{2} \cdot \mathrm{H}_{2} \mathrm{O}$} & \multicolumn{2}{|c|}{$\mathrm{F}_{2}-\mathrm{H}_{2}-\mathrm{H}_{2} \mathrm{O}$} & \multicolumn{2}{|c|}{$1 / 2 \mathrm{O}_{2}-\mathrm{H}_{2}$} & $\mathrm{OF}_{2}$ \\
\hline & $\%$ & $\mathrm{~kJ} \mathrm{~mol}^{-1}$ & $\%$ & $\mathrm{~kJ} \mathrm{~mol}^{-1}$ & $\%$ & $\mathrm{~kJ} \mathrm{~mol}^{-1}$ & $\mathrm{~kJ}^{-1}$ \\
\hline $\begin{array}{l}\text { Random errors: } \\
\text { Calibration }\left(\sigma_{c}\right) \ldots \ldots \ldots \ldots \ldots \ldots \ldots \ldots\end{array}$ & 0.015 & 0.14 & 0.015 & 0.05 & 0.015 & 0.04 & \\
\hline Reaction measurement $\left(\sigma_{r}\right) \ldots \ldots \ldots \ldots$ & .015 & .14 & .034 & .11 & .042 & .12 & \\
\hline Imprecision $2 \sqrt{\sigma_{c}^{2}+\sigma_{r}^{2}} \ldots$ & 0.042 & 0.40 & 0.074 & 0.24 & 0.089 & 0.25 & 1.13 \\
\hline Systematic errors: & & & & & & & \\
\hline $\begin{array}{l}\text { Irrelevance of calib................... } \\
\text { Transient } \ldots \ldots \ldots \ldots \ldots \ldots \ldots \ldots \ldots \ldots \ldots \ldots \ldots \ldots \ldots\end{array}$ & $\begin{array}{r}0.02 \\
02\end{array}$ & $\begin{array}{r}0.19 \\
19\end{array}$ & $\begin{array}{r}0.02 \\
02\end{array}$ & 0.06 & $\begin{array}{r}0.02 \\
02\end{array}$ & $\begin{array}{r}0.06 \\
06\end{array}$ & \\
\hline 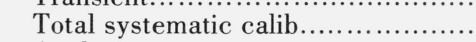 & .028 & .27 & .028 & .09 & .028 & .08 & 0.01 \\
\hline Analysis.............................. & .02 & .19 & .02 & .06 & & & \\
\hline Corrosion............................. & .02 & .19 & .02 & .06 & & & \\
\hline Total chemical................. & .028 & .27 & .028 & .09 & & & .45 \\
\hline 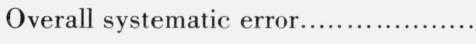 & 0.040 & 0.38 & 0.040 & 0.13 & 0.028 & 0.08 & 0.46 \\
\hline Uncertainty................... & 0.082 & 0.78 & 0.114 & 0.37 & 0.117 & 0.33 & 1.59 \\
\hline Uncertainty $\left(\mathrm{kcal} \mathrm{mol}^{-1}\right) \ldots$. & & 0.19 & & 0.09 & & 0.08 & 0.38 \\
\hline
\end{tabular}
obtain their contributions to the uncertainty in the heat of formation of $\mathrm{OF}_{2}$. These contributions, listed

TABLE 11. Summary of errors 
in the right-hand column of table 11, are added to obtain $1.59 \mathrm{~kJ} \mathrm{~mol}^{-1}\left(0.38 \mathrm{kcal} \mathrm{mol}^{-1}\right)$ for the uncertainty in the heat of formation of $\mathrm{OF}_{2}(\mathrm{~g})$.

Recent experiments in this laboratory have indicated that to obtain accurate heat measurements in calorimetric studies such as these, using the Dickinson calorimeter, the chemical energy and the energy from the calibration heater should be liberated at nearly the same position in the calorimeter [16]. This would tend to cancel the effect of temperature gradients on the surface of the calorimeter. In the experiments described in this paper, the heater was near the side of the calorimeter (closer to the thermometer), whereas the reaction vessel was near the center. The earlier investigation shows that the energy equivalent determined from the electrical energy measurements may be inappropriate for the calorimeter as used in the chemical energy measurements. This possible uncertainty in the calibration is listed here as the "irrelevance" error and is estimated to have an upper limit of 0.02 percent for these experiments. It is noted that this error probably affects all of the heat measurements by the same fractional amount. It would thus cause an effect too small to be observed in the heat of formation of $\mathrm{OF}_{2}$ which is calculated from differences between the measurements reported here; however, it could have an observable effect on the values for $\Delta H_{f 298.15}^{\circ}\left[\mathrm{HF} \cdot 50 \mathrm{H}_{2} \mathrm{O}\left[(\mathrm{l})\right.\right.$ and $\Delta H_{f 298.15}^{\circ}\left[\mathrm{H}_{2} \mathrm{O}(\mathrm{l})\right]$. The close agreement of the value found for the latter quantity with that reported by Rossini suggests that no important error is involved.

The "transient" effect has already been discussed in the description of the calibration procedures. Exact measurements of the effect were not made, but the maximum systematic error that could arise from this source was calculated to be 0.02 percent.

On the basis of earlier work $[1,2]$, we believe that the error in the analysis of the fluorine sample is 0.02 percent. Assuming that this amount of uncertainty is distributed among the $\mathrm{F}_{2}, \mathrm{~N}_{2}$, and $\mathrm{O}_{2}$ analyses, different values for $n_{\mathrm{HF}}$ (calc), $q_{\mathrm{O}_{2}}$, and $q$ (corros) are obtained (table 12). The variations amount to less than .02 percent.

We can demonstrate the validity of the overall corrosion correction applied in the following way. In figure 5 we have plotted the heats of reaction, corrected and uncorrected for corrosion, versus the percentage correction for corrosion for the $\mathrm{F}_{2}-\mathrm{H}_{2}-\mathrm{H}_{2} \mathrm{O}$

TABLE 12. $\mathrm{F}_{2}-\mathrm{H}_{2}-\mathrm{H}_{2} \mathrm{O}$ reaction

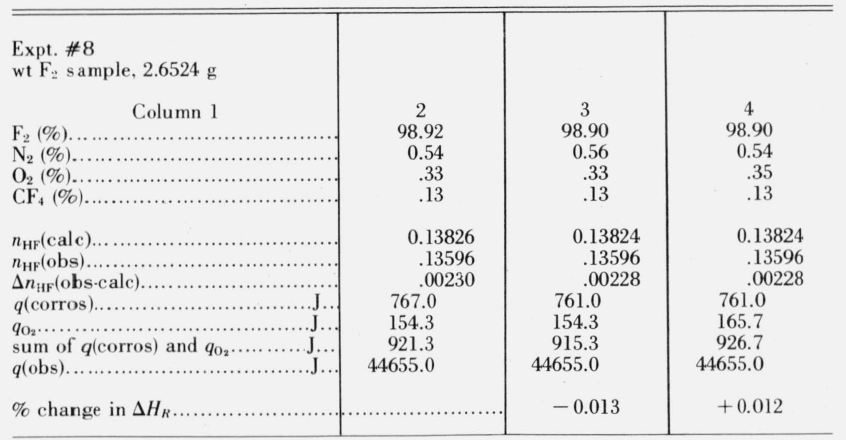

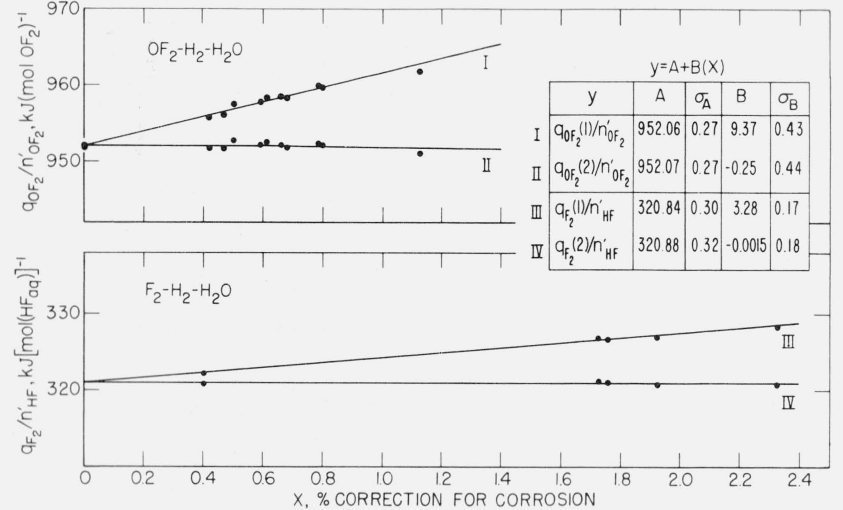

Figure 5. Plot showing the variation of the heats of the $\mathrm{F}_{2}-\mathrm{H}_{2}-\mathrm{H}_{2} \mathrm{O}$ and $\mathrm{OF}_{2}-\mathrm{H}_{2}-\mathrm{H}_{2} \mathrm{O}$ reactions versus the percentage correction for corrosion.

$(\mathrm{X}=q(\operatorname{corros}) \times 100 / q(1)$, tables 7 and 9$)$

and $\mathrm{OF}_{2}-\mathrm{H}_{2}-\mathrm{H}_{2} \mathrm{O}$ reactions. The data plotted are obtained from tables 7 and 9 , respectively. The data were fitted to the lines shown by the method of least squares and the equations are shown on the illustration. For both reactions there is a linear variation of the uncorrected heat of reaction with the $q$ (corros) which was essentially eliminated, when $q$ (corros) was applied. This illustration also shows why, in tables 8 and 10, the standard deviation of the mean of $\Delta H(3)$ is much less than for $\Delta H(2)$. The application of $q$ (corros) smooths out an effect present in varying degrees in each of the experiments.

\section{The Heat of Formation of Oxygen Difluoride. The (O-F) Bond Energy}

We summarize the heat measurements and the heat of formation of $\mathrm{OF}_{2}$ in table 13 . The calculated heat of formation at $303.4{ }^{\circ} \mathrm{K}$ becomes the same value at $298.15^{\circ} \mathrm{K}$ to yield $\Delta \mathrm{H}_{f 298.15}^{\mathrm{p}}\left[\mathrm{OF}_{2}(\mathrm{~g})\right]=+5.86 \pm 0.38 \mathrm{kcal}$ $\mathrm{mol}^{-1}$. The uncertainty shown represents the estimated accuracy based on the errors discussed. The value for the average $\mathrm{O}-\mathrm{F}$ bond energy in $\mathrm{OF}_{2}$ is calculated from this value for $\Delta H_{f}^{\circ}\left[\mathrm{OF}_{2}(\mathrm{~g})\right]$, using $\Delta H_{f}^{\circ}[\mathrm{O}(\mathrm{g})]=59.553$, and $\Delta H_{f}^{\circ}[2 \mathrm{~F}(\mathrm{~g})]=37.75 \mathrm{kcal} \mathrm{mol}^{-1}$ [8], to be $45.72 \mathrm{kcal} \mathrm{mol}^{-1}$.

TABLE 13. The heat of formation of $\mathrm{OF}_{2}$

\begin{tabular}{l|l}
\hline & \multicolumn{2}{|c}{$\Delta H_{R, 303}{ }^{\circ} \mathrm{K}$ kcal } \\
\cline { 2 - 2 } $\mathrm{OF}_{2}(\mathrm{~g})+2 \mathrm{H}_{2}(\mathrm{~g})+99 \mathrm{H}_{2} \mathrm{O}(\mathrm{l}) \longrightarrow 2\left[\mathrm{HF} \cdot 50 \mathrm{H}_{2} \mathrm{O}\right](\mathrm{l})$ & $-227.52 \pm 0.19$ \\
$\mathrm{~F}_{2}(\mathrm{~g})+\mathrm{H}_{2}(\mathrm{~g})+100 \mathrm{H}_{2} \mathrm{O}(\mathrm{l}) \longrightarrow 2\left[\mathrm{HF} \cdot 50 \mathrm{H}_{2} \mathrm{O}\right](\mathrm{l})$ & $-153.38 \pm 0.18$ \\
$\mathrm{l} / 2 \mathrm{O}_{2}(\mathrm{~g})+\mathrm{H}_{2}(\mathrm{~g}) \longrightarrow \mathrm{H}_{2} \mathrm{O}(\mathrm{l})$ & $-68.28 \pm 0.08$ \\
\hline $\mathrm{F}_{2}(\mathrm{~g})+1 / 2 \mathrm{O}_{2}(\mathrm{~g}) \longrightarrow \mathrm{OF}_{2}(\mathrm{~g}) \Delta H_{\rho_{2} 98.15}^{\circ}\left[\mathrm{OF}_{2}(\mathrm{~g})\right]=+5.86 \mathrm{kcal} \pm 0.38$
\end{tabular}

In table 14 we give the reactions investigated in the earlier work and compare the value reported for $\Delta \mathrm{H}_{f 298.15}^{\circ}\left[\mathrm{OF}_{2}(\mathrm{~g})\right]$ with the value $[+5.86 \pm 0.38 \mathrm{kcal}$ 


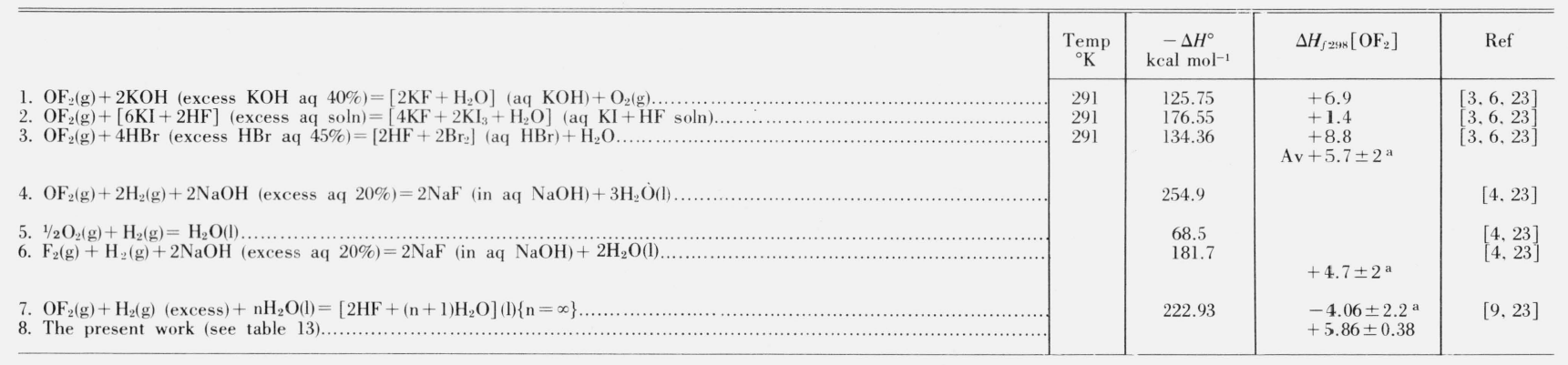

a Estimated overall uncertainty given in original report.

$\mathrm{mol}^{-1}$ ] derived from the present study. Our value agrees consistently with those reported by von $\mathrm{W}$ artenberg and Klinkott $\left[+5.7 \pm 2 \mathrm{kcal} \mathrm{mol}^{-1}\right]$, and Ruff and Menzel [ $\left.+4.7 \pm 2 \mathrm{kcal}^{-1} \mathrm{~mol}^{-1}\right]$, but differs from Bisbee's results $\left[-4.06 \pm 2.2 \mathrm{kcal} \mathrm{mol}^{-1}\right]$.

In the various reviews which have been conducted on these studies so far, the biggest improvement in the re-evaluation of the original data has been to substitute current auxiliary data for the reactions studied by von Wartenberg and Klinkott. Ruff and Menzel measured the heats of principal reaction (4) and the auxiliary reactions ((5) and (6)) for calculating their value for $\Delta H_{2298.15}^{\circ}\left[\mathrm{OF}_{2}\right]$. Bisbee's value for $\Delta H_{f 298.15}^{\circ}\left[\mathrm{OF}_{2}\right]$ will change as improvements are made in the $\Delta H_{f 298.15}^{\circ}[\mathrm{HF}$, aq, $\infty]$, the principal auxiliary data on which their results are based. However, it seems unlikely that the $\Delta H_{f 298.15}^{\circ}[\mathrm{HF}$, aq, $\infty]$ will ever be revised by an amount that will change the sign of their value for $\Delta H_{f 298.15}^{\circ}\left[\mathrm{OF}_{2}\right]$.

No attempt will be made here to review completely the earlier studies. However, in re-examining the work of Bisbee et al., we note several points about their experiments which may lead to a less negative observed heat of reaction, and therefore explain the more negative heat-of-formation value which they reported. They give little information on the (1) analysis of the sample, (2) the technique used to insure mixing of the solution, (3) the corrosion by the product HF, and (4) the quantitative basis for the heat of reaction. Each of these aspects of their experiments is very important in the accuracy of the work. For example, oxygen is a usual impurity in the $\mathrm{OF}_{2}$ produced by the present-day method $\left(\mathrm{F}_{2}+\mathrm{NaOH}\right)$ and would react with $\mathrm{H}_{2}$ under the conditions of these experiments. These authors mention no test for oxygen and therefore no correction for its heat of reaction.

The measurements were made in a stationary bomb, using a fairly massive internal container for $\mathrm{OF}_{2}(\mathrm{~g})$ which was ruptured to initiate reaction with $\mathrm{H}_{2}$. The reaction products consisted of $\mathrm{H}_{2} \mathrm{O}$ and $\mathrm{HF}$ in a condensed phase, formed in the presence of excess $\mathrm{H}_{2} \mathrm{O}(\mathrm{l})$. The formation of a homogeneous $\mathrm{HF}(\mathrm{aq})$ phase was presumed. However, experience in reactions in which condensation occurs in a stationary bomb indicates that much of the condensation would occur on the walls and would form droplets of a solution quite different from the bulk solution. Mixing these two solutions would evolve heat in addition to that which was measured. The massive $\mathrm{OF}_{2}$ ampoule could also retain significant quantities of heat for an appreciable time, and the complete equilibration of the heat distribution was not described. Both of these processes would appear to act in the same direction, causing the measured amount of heat to be less than could have been evolved if equilibrium had been achieved. If any errors of these types exist in the experiments, a less negative heat of formation would be indicated for $\mathrm{OF}_{2}$ than was reported.

The authors wish to acknowledge assistance received from several staff members of the National Bureau of Standards. Mr. James Baylor of the Shops Division made several valuable suggestions for the design of the reaction vessel. Mr. William Dorko and Mr. E. E. Hughes performed the mass spectrometric analyses, and Mr. T. C. Rains performed the analyses for metal ions in the hydrofluoric acid solutions.

\section{Appendix}

\subsection{The Aıralyses of the Oxidizer Gases}

a. Oxygen

The oxygen sample was transferred from the large cylinder to the weighing containers with a manifold of a type also used for filling oxygen combustion bombs [16]. Prior to being filled the container was evacuated and then purged three times with 2-3 atm of oxygen. Finally, the container was filled to about 14 atm. Although further purification probably was unnecessary, during the filling procedure the oxygen was passed through a column of $\mathrm{CuO}$, heated to $500{ }^{\circ} \mathrm{C}$, and through successive columns of Ascarite and magnesium perchlorate.

The oxygen in the weighing bulb was analyzed for argon by mass spectrometry. The concentration of argon was found to be $29 \pm 10$ parts per million. Nitrogen was determined by gas chromatography using the method reported by Kyryacos and Boord [24]. The equipment consisted of a commercially available chromatograph equipped with an electrically 
heated column oven, a thermal conductivity cell, and a strip-chart recording potentiometer $(-0.2$ to $+1.0 \mathrm{mV}$ ). Molecular Sieve Type $5 \mathrm{~A}$ was used as column material with helium as carrier gas. The sample was introduced into the column with a commercial gas sampling valve, modified with a $10-\mathrm{cm}^{3}$ sample loop. Nitrogen could not be detected in smaller samples. The reliability of the method was checked with one- $\mathrm{cm}^{3}$ samples of air.

The conditions are given on the chromatogram in figure 6 . The small effect attributed to nitrogen was quite reproducible, and verified by the injection of air.

\section{b. Fluorine}

The fluorine was transferred to the spherical sample containers using the manifold and apparatus shown in figure 7 . The general procedure for filling the containers consists of (1) evacuating the containers and connecting lines, (2) conditioning and purging the manifold and parts of the connected apparatus with fluorine, (3) filling the bulbs to the desired pressure, and (4) disposing of the fluorine in the connecting lines. To insure that the bulbs were conditioned thoroughly, they were filled repeatedly with a low pressure of fluorine (2 atm), and emptied. Finally they were filled to a working pressure of 13 atm.

Mercury absorption is a well-known technique and has been used extensively for the analysis of fluorine $[1,25,26]$. Although this method appears to be satisfactory, there is some question as to whether the mercury selectively absorbs fluorine from other reactive gases like $\mathrm{NF}_{3}$ and $\mathrm{OF}_{2}$ which possibly are present as impurities. These substances may react with mercury under the conditions of the test and produce some $\mathrm{N}_{2}$ and $\mathrm{O}_{2}$ which are the major impurities ordinarily contained in fluorine.

The chromatographic procedures developed for analysis of the residual gas are independent of the mass spectrometric method. However, the qualitative

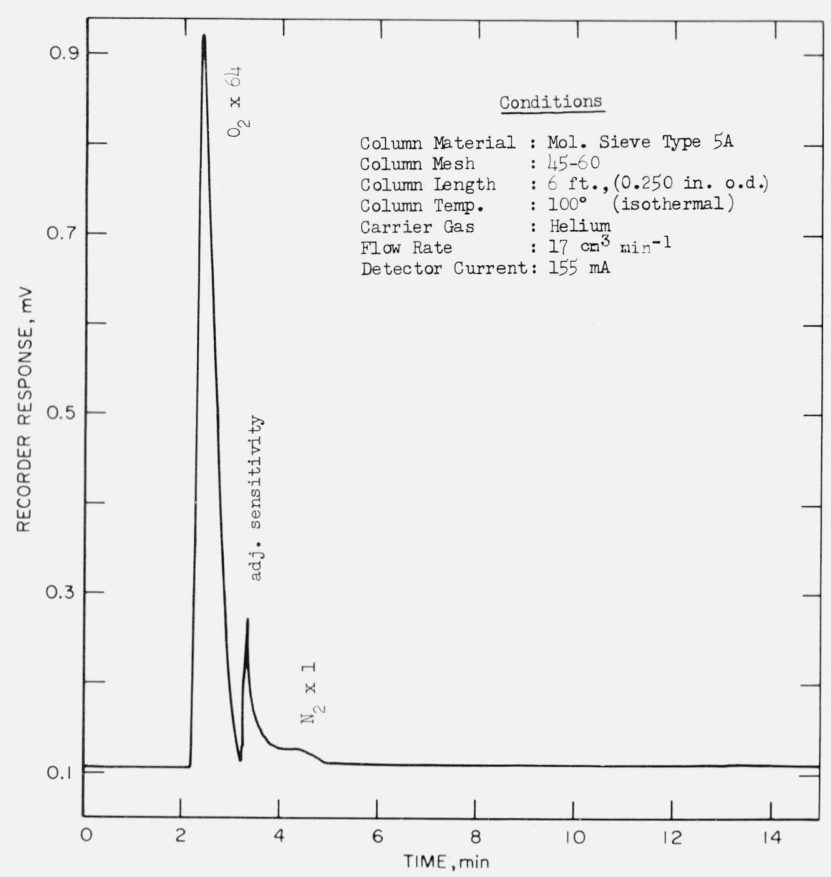

Figure 6. Chromatogram of the oxygen sample on Molecular Sieve Type $5 \mathrm{~A}$.

identification of the impurities obtained in the latter method is useful for selection of chromatographic column materials.

In addition to the usual chromatographic equipment, the method developed requires (1) a fluorine source, (2) a flask containing mercury for reaction of the fluorine, (3) a loop for containing chromatographic samples of the residual gas, (4) a soda-lime column for disposal of fluorine, and (5) a vacuum source. All of these items were arranged around a manifold as shown in figure 8 .

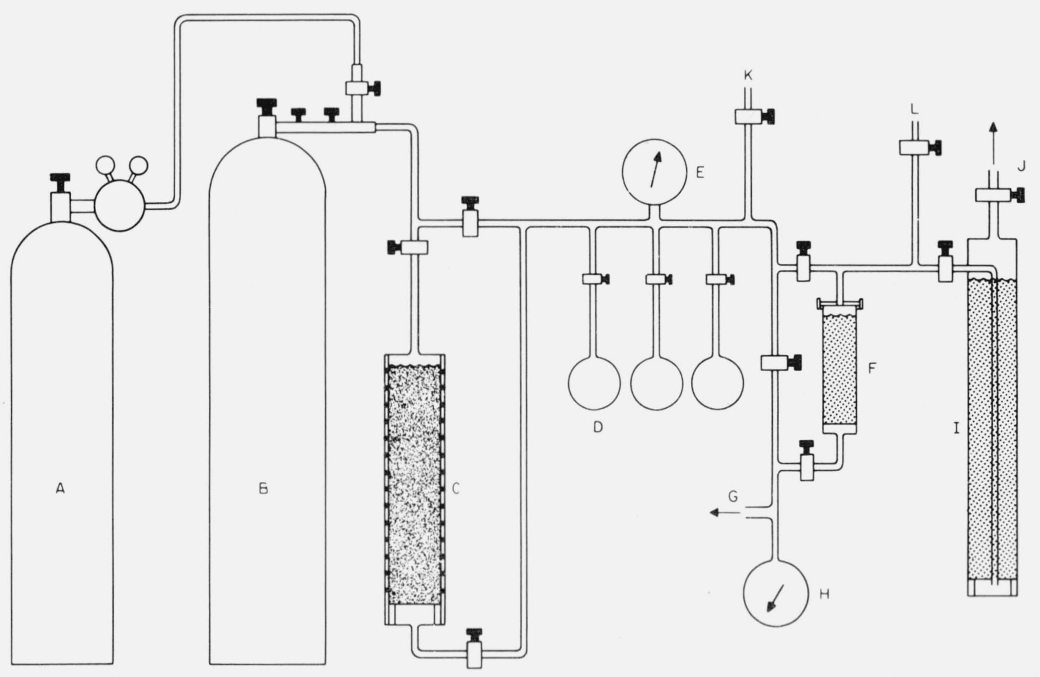

FigURE 7. Gas sampling manifold and connected apparatus $\left(\mathrm{F}_{2}\right.$ and $\left.\mathrm{OF}_{2}\right)$.

A, Nitrogen; B, Fluorine or oxygen difluoride; C, Sodium fluoride column; D, Sample bulbs; E, Pressure gauge F, Fluorine absorption tower; G, Vacuum source; H. Vacuum gauge; I, Fluorine absorption tower; J, Outlet to hood; K, L, to calorimeter flow system. 


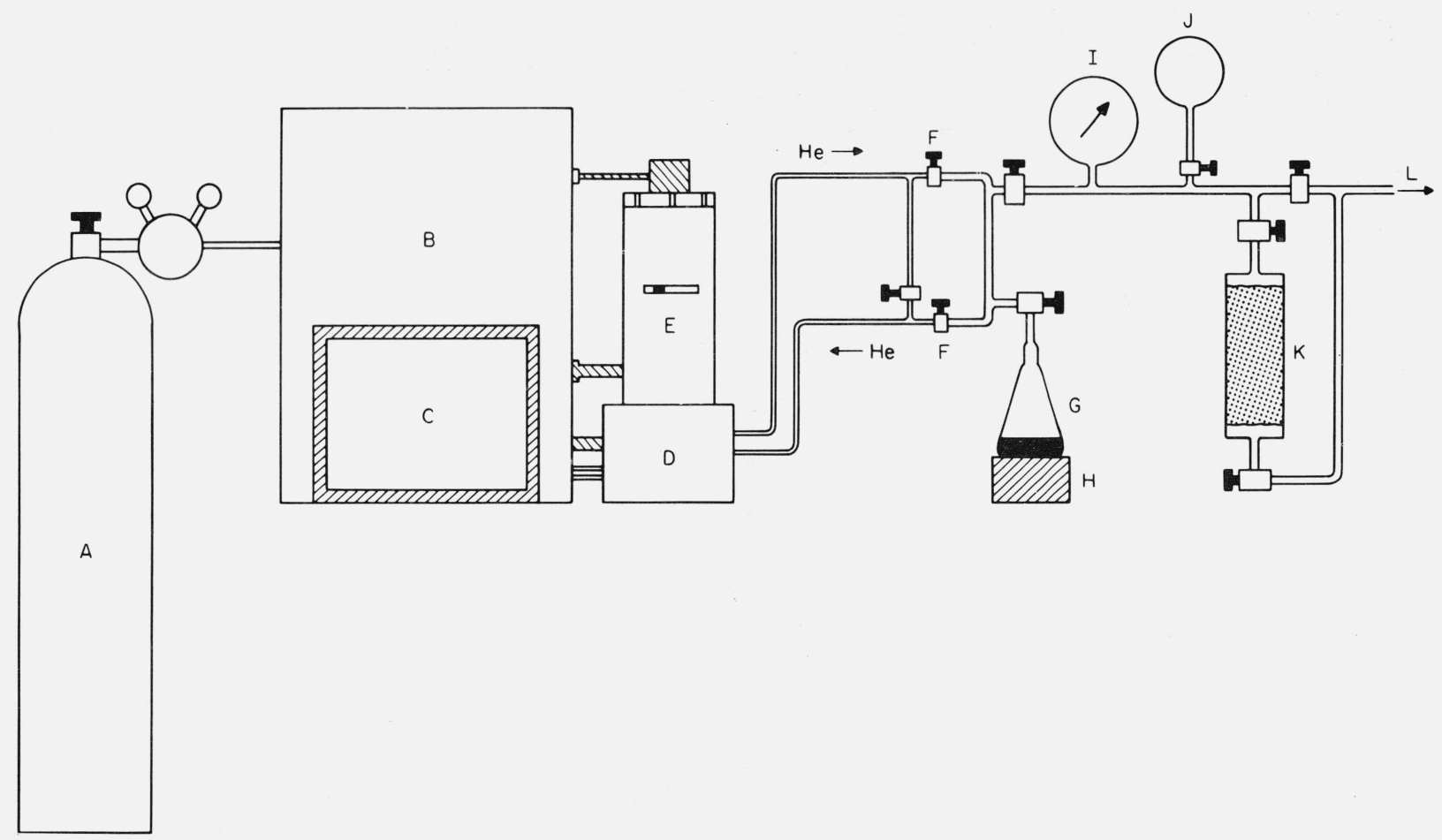

FIGURE 8. Manifold and apparatus for chromatographic analysis of impurities in fuorine.

A, Helium; B, Chromatograph; C, Recorder; D, Detector block; E, Column heater; F, Valves; G, Flask with mercury $\left(300-\mathrm{cm}^{3}\right.$ flask); H, Magnetic stirring motor; I, Vacuum gauge; J, Fluorine sample; K, Fluorine absorption tower; L, Vacuum source.

The equipment preceding valves $(\mathrm{F})$ is ordinarily used in chromatographic analyses and has been described for the oxygen analyses. The steps in the preparation of the system to receive the sample are: (1) close valves (F) and then evacuate remaining parts of system; (2) close flask and admit small amount of fluorine from container $(\mathrm{J})$ for conditioning manifold; and (3) remove fluorine from lines by evacuation through soda-lime column (K). The conditioning procedure is repeated several times. The sample is then introduced by placing one atm of fluorine in the flask. A surface film forms on the mercury which prevents further reaction until the mercury is agitated. The flask contains a Teflon-covered magnet and is placed on a magnetic stirring motor so that the mercury can be agitated with the flask in place. However, to insure complete reaction of the fluorine, it is preferable to disconnect the flask from the manifold so that it can be shaken vigorously by hand. After the fluorine has completely reacted, the flask is reconnected to the manifold and the sample loop is evacuated. Appropriate valves are adjusted so that when the flask is opened the residual gas expands into the sample loop. To introduce the sample into the chromatograph, the valves are adjusted so that the helium from the chromatograph flushes the residual gas into the column. The reaction flask is left in place so that the analyses can be repeated.

Mass spectrometric analyses on other samples of residual gas from commercial fluorine had shown that the major impurities were nitrogen, oxygen, carbon tetrafluoride, and carbon dioxide, with smaller amounts of silicon tetrafluoride, sulfur hexafluoride and fluorocarbons. On this basis Molecular Sieve Type 5A and silica gel were selected for the chromatographic column materials. Molecular Sieve Type 5A, used in the procedure of Kyryacos and Boord [24], separates nitrogen from oxygen, but shows no separation efficiency toward the other impurities. Silica gel [10] separates oxygen plus nitrogen from the carbon tetrafluoride and carbon dioxide. Typical chromatograms are shown in figures 9 and 10, respectively. The conditions for the analyses are given on the chromatograms. The peak components were checked with injections of air, pure carbon tetrafluoride and carbon dioxide. Prior to the analyses both columns were conditioned at $300{ }^{\circ} \mathrm{C}$ under a flowing helium atmosphere.

After the chromatographic analyses, the sample loop was disconnected from the chromatograph at the two valves, F. On one valve a Pyrex breakofftip type ampoule was attached, and the ampoule and connecting lines were evacuated. The ampoule was filled with residual gas from the flask and sealed. A mass spectrometric analysis was performed on this sample. The results from the two methods are compared in table 15. Considering that these are two completely different techniques, the results are in good agreement. This agreement suggests that the chromatographic method may be developed further and used routinely as a second way of analysing for the impurities in ordinary commerical fluorine, which is usually reported to be of a purity of not better than 98 percent. 


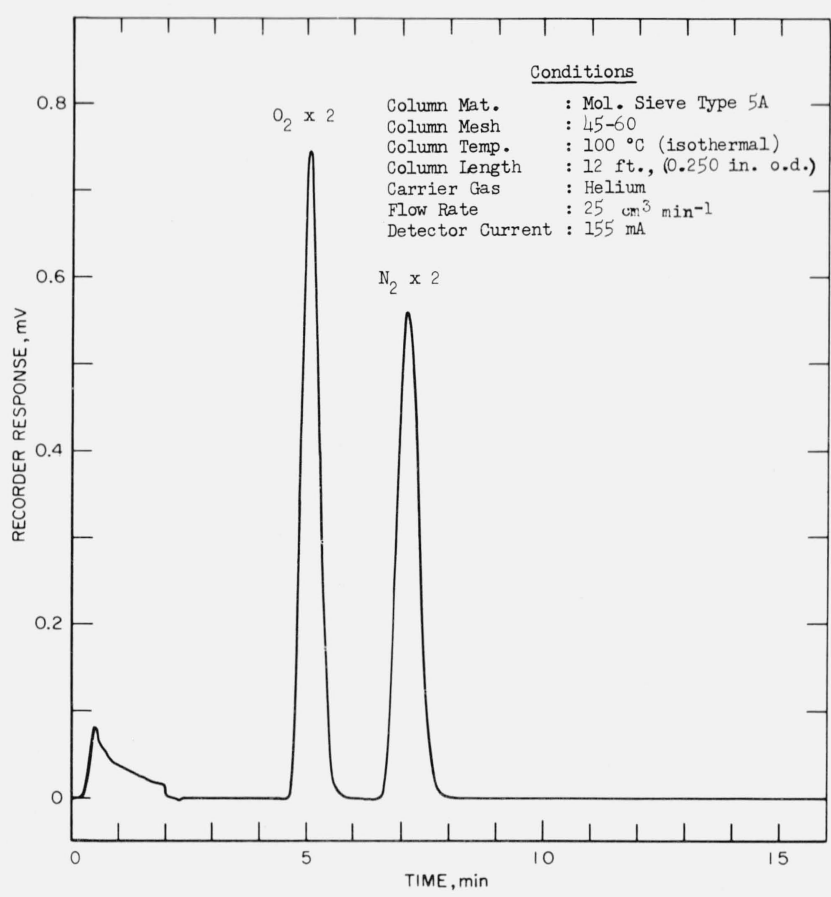

FigURE 9. Chromatogram of impurities in the fluorine sample on Molecular Sieve Type $5 \mathrm{~A}$.

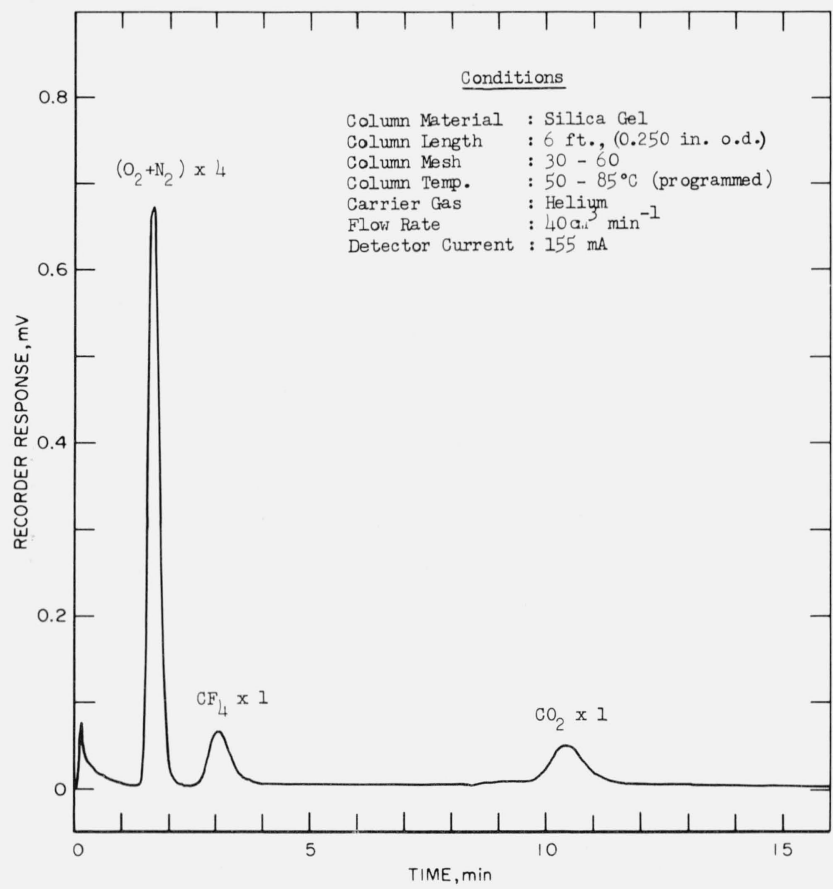

FIGURE 10. Chromatogram of Impurities in the fuorine sample on silica gel.

The data in tables 1 and 15 show a difference between the relative amounts of oxygen and nitrogen in the residual gas in the flask used for chromatography, compared to the residual gas used from the
TABLE 15. Comparison of chromatographic and mass spectrometric analyses for impurities in fluorine

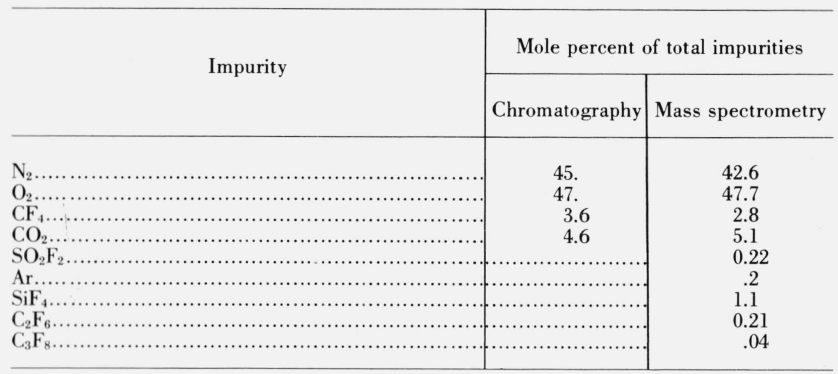

spherical bulbs. The larger amount of oxygen impurity in the Erlenmeyer flask suggests that some oxygen may have arisen from the mercury because there was $1000 \mathrm{~g}$ mercury in the Erlenmeyer flask, as compared to $150 \mathrm{~g}$ of mercury in the flask used for the analysis given in table 1 . There is reason to believe that the analysis can be improved by conditioning the mercury and flask surfaces also with a small amount of fluorine, prior to filling the flask with the one atmosphere of gas needed for the analysis.

\section{c. Oxygen Difluoride}

The oxygen difluoride was transferred to the sample containers using the same manifold and equipment shown in figure 7 . The procedures used were the same as those used in sampling the fluorine, except that the oxygen difluoride was not passed over the sodium fluoride. The sample containers were filled to approximately 8 atm with $\mathrm{OF}_{2}$.

An infrared spectrum of the oxygen difluoride sample was made and compared with spectra in the literature [27, 28]. The cell was Pyrex with silver chloride windows. The windows were clamped in place and sealed to the cell with Kel-F O-rings. The spectrum is shown in figure 11. An absorption band presumed to be due to the impurity $\mathrm{CF}_{4}$, is indicated.

The equipment used for the chromatographic analyses already has been described for the oxygen and fluorine analyses. The $\mathrm{OF}_{2}$ sample container is connected to a loop which can be purged with helium from the chromatograph. Silica gel was used for the column material. Prior to the analyses, the column was conditioned at $350^{\circ}$ for one hour under a flowing helium atmosphere. The other conditions for the analyses are given on figures 12 and 13 which show the chromatograms obtained.

In the complete chromatogram, four peaks were obtained. These were verified to be due to $\mathrm{O}_{2}$ (or air), $\mathrm{OF}_{2}, \mathrm{CF}_{4}$, and $\mathrm{CO}_{2}$. Analyses were made with the column temperature at $0^{\circ}$ and $50{ }^{\circ} \mathrm{C}$. At $0{ }^{\circ} \mathrm{C}$ nearly complete separation was achieved between the $\mathrm{O}_{2}$ and $\mathrm{OF}_{2}$ (figure 12), but the $\mathrm{CO}_{2}$ peak was either very slurred or the fraction did not elute at this temperature. At $50{ }^{\circ} \mathrm{C}$, the separation between the $\mathrm{O}_{2}$ and $\mathrm{OF}_{2}$ was poor but separation and elution of $\mathrm{CO}_{2}$ could be obtained by temperature programming. After elution of the $\mathrm{O}_{2}$ and $\mathrm{OF}_{2}$, the column was temperatureprogrammed to a final temperature of $150{ }^{\circ} \mathrm{C}$ for 


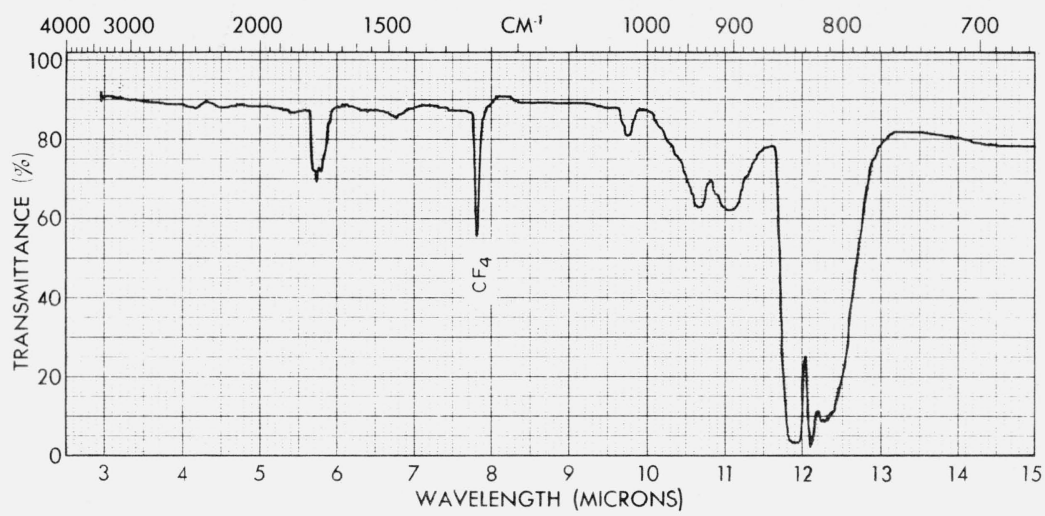

FIGURE 11. IR spectrum of the $\mathrm{OF}_{2}$ sample.

Note $\mathrm{CF}_{4}$ band at 780 microns.

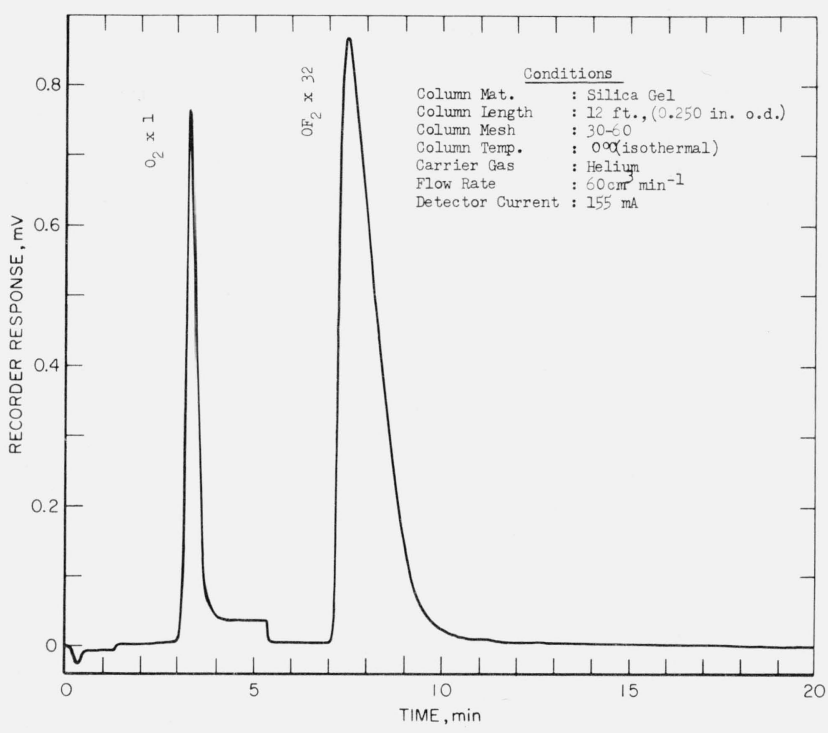

Figure 12. Chromatogram of the $\mathrm{OF}_{2}$ sample on silica gel $\left(0^{\circ} \mathrm{C}\right)$.

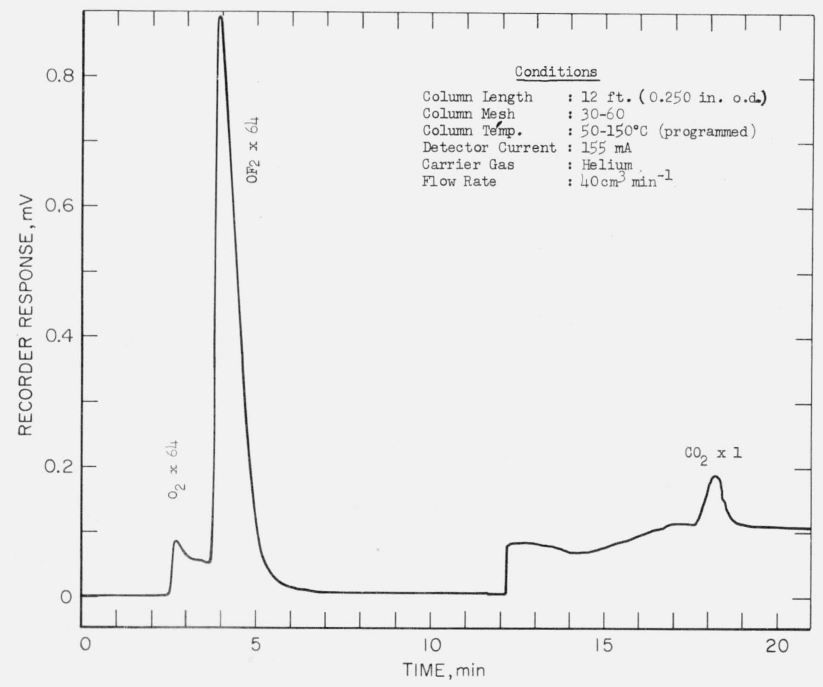

Figure 13. Chromatogram of the $\mathrm{OF}_{2}$ sample on silica gel $\left(50{ }^{\circ} \mathrm{C}\right)$. (The column was programmed to $150^{\circ} \mathrm{C}$ beginning at 12 mins.) elution of the $\mathrm{CO}_{2}$ (fig. 13). In agreement with Kesting's observations [10], the $\mathrm{CF}_{4}$ eluted on the "tail" of the $\mathrm{OF}_{2}$ fraction. The $\mathrm{CF}_{4}$ peak was evaluated from other chromatograms obtained with the instrument set on the most sensitive scale.

Repeated analyses were made on several bulb fillings and the results were quite reproducible. We accepted the findings of Kesting, et al. [10], that the peak area percent for the observed components $\left(\mathrm{OF}_{2}, \mathrm{CO}_{2}\right.$, $\mathrm{O}_{2}, \mathrm{CF}_{4}$ ) was very nearly equal to mole percent. The peak areas were evaluated both analytically and by counting squares.

Several preliminary analyses were carried out before a procedure was accepted for these experiments. Because of the reactivity of the $\mathrm{OF}_{2}$, it is conceivable that $\mathrm{OF}_{2}$ reacts with the silica gel. During preliminary analyses at various column temperatures, it was noted that extraneous peaks appeared at a temperature of $75^{\circ} \mathrm{C}$, and also that even at $50^{\circ}$, the mole percent of $\mathrm{OF}_{2}$ decreased while the mole percent of $\mathrm{O}_{2}$ increased. These preliminary analyses suggest that silica gel is not a generally useful column material for chromatographic analyses of the reactive inorganic fluorides. However, under the proper conditions silica gel has good separation efficiency toward $\mathrm{OF}_{2}$ and inert component impurities such as $\mathrm{O}_{2}$ and $\mathrm{CF}_{4}$.

\section{References}

[1] G. T. Armstrong and R. S. Jessup, J. Res. NBS 64A (Phys. and Chem.) No. 1, 49 (1960).

[2] G. T. Armstrong, Experimental Thermochemistry, Vol. II., Ch. 7, ed. H. A. Skinner (Interscience Publishers, Inc., New York, N.Y., 1962)

[3] H. v. Wartenberg and G. Z. Klinkott, Z. anorg. u. allgem. Chem. 193, 409 (1930).

[4] O. Ruff and W. Menzel, Z. anorg. u. allgem. Chem. 190, 257 (1930).

[5] W. H. Evans, T. R. Munson, and D. D. Wagman, J. Res. NBS 55, 147 (1955) RP2614.

[6] R. C. King and G. T. Armstrong, Interagency Chemical Rocket Propellant Group, Thermochemistry Working Group, Bulletin of the Fifth Meeting March 15-17, 1967, Vol. 1., Chemical Propulsion Information Agency, Publication CPIA No. 146, pp. 69-96, May 1967. 
[7] JANAF Thermochemical Tables, PB 168370, Dow Chemical Co., Midland, Michigan (Clearinghouse for Federal Scientific and Technical Information, Springfield, Va., August 1966).

[8] D. D. Wagman, W. H. Evans, I. Halow, V. B. Parker, S. M. Bailey, and R. H. Schumm, Selected Values of Chemical Thermodynamic Properties, Part 1. Tables for the First Twenty-Three Elements in the Standard Order of Arrangement, NBS Tech. Note 270-1 (U.S. Government Printing Office, W ashington, D.C. 20402, 1965).

[9] W. R. Bisbee, J. V. Hamilton, R. Rushworth, T. J. Houser, and J. M. Gerhauser, Advan. Chem. Ser. 54, 215 (1965).

[10] W. R. Kesting, General Chemical Division, Allied Chem. Corp., Baton Rouge, La., private communication; W. R. Kesting, J. E. Crosslin, and B. W. Bridwell, Analysis of Oxygen Difluoride, Report of the Analytical Chemistry Working Group, 22nd Meeting, ed., John W. Gunn, Jr. (Chemical Propulsion Information Agency, Nov. 3, 1965. )

[11] J. C. Brosheer, F. A. Lenfesty, and K. L. Ellmore, Ind. Eng. Chem. 39, 423 (1947).

[12] H. C. Dickinson, Bull. BS 11, 189 (1915).

[13] E. J. Prosen, W. H. Johnson, and F. Y. Pergiel, J. Res. NBS 62, 43 (1959) RP2927.

[14] E. D. West and D. C. Ginnings, Rev. Sci. Instr. 28, 1070 (1957).

[15] D. C. Ginnings and E. D. West, Rev. Sci. Instr. 35, 965 (1964).

[16] K. L. Churney and G. T. Armstrong, submitted for publication J. Res. NBS.
[17] C. H. Shomate, Computer Calculations of Combustion Bomb Calorimetric Data, Technical Progress Report 327, NOTS TP 3288, U.S. Naval Ordnance Test Station, China Lake, Calif., August 1963.

[18] A. E. Cameron and E. Wichers, J. Am. Chem. Soc. 84, 4175 (1962).

[19] N. S. Osborne, H. F. Stimson, and D. C. Ginnings, J. Res. NBS 23, 197 (1939) RP1228.

[20] T. Thorvaldson and E. C. Bailey, Can. J. Res. 24, 51 (1946).

[21] F. D. Rossini, J. Res. NBS 6, 1 (1931) R.P.259; see also Chapter 4 Experimental Thermochemistry, ed. F. D. Rossini (Interscience Publishers, Inc., New York, N.Y., 1956).

[22] E. Rudzitis, E. H. Van Deventer, and W. N. Hubbard, J. Chem. Eng. Data 12, 133 (1967).

[23] W. H. Evans, National Bureau of Standards, private communication.

[24] G. Kyryacos and C. E. Boord, Anal. Chem. 29, 787 (1957).

[25] L. A. Bigelow, Chem. Revs. 40, 110 (1947).

[26] H. Schmitz and H. J. Schumacher, Z. anorg. u. allgem. Chem. $\mathbf{2 4 5}, 221$ (1940)

[27] H. J. Bernstein and J. Powling, J. Chem. Phys. 18, 685 (1950).

[28] E. A. Jones, J. S. Kirby-Smith, P. J. H. Woltz, and A. H. Nielsen, J. Chem. Phys. 19, 337 (1951).

(Paper 72A2-487) 